Bangladesh J. Plant Taxon. 28(1): 171-193, 2021 (June)

(C) 2021 Bangladesh Association of Plant Taxonomists

https://doi.org/10.3329/bjpt.v28i1.54216

\title{
LEAF EPIDERMAL ANATOMY OF CYNODON DACTYLON (L.) PERS. IN RELATION TO ECOTYPIC ADAPTATION
}

\author{
S.K. NITU ${ }^{1,2}$, H. TARIQUE ${ }^{3}$ AND S.M.S. ISLAM ${ }^{1} *$ \\ Plant Biotechnology and Genetic Engineering Lab., Institute of Biological Sciences, \\ University of Rajshahi, Rajshahi-6205, Bangladesh
}

Keywords: Anatomy; Cynodon dactylon; Leaf epidermis; Stomatal features.

\begin{abstract}
Qualitative and quantitative studies were done on leaf epidermal characteristics with special reference to stomatal features to find out the impact of environmental condition on twenty four accessions of Cynodon dactylon (L.) Pers. collected from different ecological habitats of Bangladesh. The foliar epidermal peels from both surfaces of mature leaves were observed under microscope. The leaves were found to be amphistomatic and stomata were paracytic type. The epidermal cells in this study were found to be sinuous. Silica bodies were found to be saddle and cross shaped. Prickles angular were pointed at the tip. Macro-hairs were present in all the accessions, but no micro-hair was found both adaxially or abaxially. Stomatal frequency and stomatal index were found to vary from accession to accession on both adaxial and abaxial surface of leaves, and the differences were statistically significant in most of the cases.
\end{abstract}

\section{Introduction}

Cynodon dactylon (L.) Pers is a typical warm season turfgrass belongs to the family of Poaceae and this grass species is widely adapted to various environments of tropical and subtropical regions around the world. There are some ways for genetic diversity and population structure analysis of $C$. dactylon like interphase nuclear phenotype and chromosomal characterization that are very useful parameters in distinguishing the cytotypes, accessions and even germplasm of a plant species (Nitu et al., $2019 \mathrm{a} \& \mathrm{~b}$ ).

The leaf epidermis is generally considered as an important aspect for the classification and delimitation of species and genera, and for sorting out the evolutionary and phylogenetic problems (Stace, 1984; Jones, 1986). Ahmed et al. (2011) stated that the leaf epidermal characters have significance in grass systematics and classification of ambiguous groups which are not properly adjusted within grasses, particularly at sub-family and tribe level. Therefore, it is imperative to make any attempt to study the epidermal characters of taxonomic importance. It is evidenced now that leaf epidermal features can help to elucidate many ecological parameters. In Poaceae leaf epidermal anatomy shows variations with a higher degree of specialization than that of any other family and provides extensive features of taxonomic importance. Leaf epidermal anatomical features like stomata and trichomes along with some other qualitative and quantitative characters are very much useful in perspective of morphological, ecological, physiological and taxonomical studies. The morphology and ontogenies of taxa are considered to be more important in case of intra-generic and intra-species systematics due to diversity of stomatal types. On the contrary, the most frequent stomata type is considered as taxonomic character.

*Corresponding author: shahinul68@gmail.com

${ }^{2}$ Department of Botany, University of Rajshahi, University of Rajshahi, Rajshahi-6205, Bangladesh.

${ }^{3}$ Department of Agronomy and Agriculture Extension, University of Rajshahi, Bangladesh. 
Plant anatomical traits are good indicators of habitat quality, since they manifest variability in relation to microclimatic conditions (Barber et al., 2004). Stomatal traits like stomatal density, stomatal apparatus and guard cell architecture respond to environmental and physiological cues (Nadeu and Sack, 2002; Gitz and Baker, 2009). The present study aims to identify the leaf epidermal features which may focus on stomatal characters because of their importance in many ecological aspects of grass species. Cynodon dactylon has paracytic type of stomata (Abid et al., 2007) and they are arranged in parallel rows in with silica bodies on the epidermal surface. Paracytic type is considered to be primitive and their arrangement reflects the developmental process. In $C$. dactylon stomata may be present on both side (adaxial and abaxial) of the expanded leaf, but in many grass species they are exclusively abaxial. Leaf epidermal traits i.e.; epidermal cells, stomata and micro-hairs have been proved valuable in identification and differentiation of different taxa (Stenglein et al., 2003). Macro-hairs are also found to vary in size, shape and wall thickness and these are of great value in grass systematic. The shape of silica bodies varies among different grass species from round or oblong to linear, crescent or dumbbell shaped, nodular, sinuous and shaddle or cross shaped (Chaudhary et al., 2001b; Ahmad et al., 2012; Chaudhari et al., 2014). Stomatal parameters like size, number and shape are of great ecological significance (Jian et al., 2012) and extremely important in stress tolerance (Xu and Zhou, 2008; Zheng et al., 2013). Stomatal size and shape regulate water use efficiency. In small stomata less turgour is required for their opening and closing (Tufail et al., 2017). Stomatal frequency improves the photosynthetic efficiency of plant species. The present study is focused on the qualitative and quantitative leaf epidermal characteristics with special reference to stomatal features to find out the impact of environmental conditions on $C$. dactylon.

\section{Materials and Methods}

A total of 24 accessions of Cynodon dactylon (L.) Pers. was collected from different ecological habitats in Bangladesh. Selections were based on environmental conditions of the collection site. All the accessions were planted in $1.5 \mathrm{~m} \times 1.4 \mathrm{~m}$ plots of the research field of the Institute of Biological Sciences, University of Rajshahi, Bangladesh. The site has an annual average rainfall of $661.2 \mathrm{~mm}$ of which the majority falls during the rainy season (July-September 2019). No fertilizers were used in the experimentation field. The soil at the research field is loamy soil.

Both abaxial and adaxial surface of the leaves of $C$. dactylon were studied qualitative and quantitatively which have been mentioned in Tables 1-9. The foliar epidermal peels were stained with $1 \%$ safranin and observed under microscope (SWIFT- S.A No.760090) for detailed obtaining feature as it is done usually. The photomicrographs of the mounted materials were taken using a digital camera (Model: C-B5, Brand: Optica) fitted on the electrical light microscope (Model: XSZ-107T, Brand: Novel) with total magnification of 10X in Laboratory of Phycology and Limnology, University of Rajshahi, Bangladesh. These photomicrographs were useful for identification and differentiation based on the features of epidermal cells. In case of some quantitative characters ocular micrometer was used for measurement and the values were converted into micron $(\mu)$ with the help of stage micrometer.

Observations for number of stomata present in microscopic view field was made for recording and for calculating the stomatal frequency and thereafter, expressed in terms of stomata/ $/ \mathrm{mm}^{2}$. At a given magnification the total number of stomata was counted as visible by square grid scale under microscope. The square grid was composed of 100 identical small squares. The diameter of view field was calculated by ocular scale. The stomatal index (SI) was calculated using the formula SI $=(\mathrm{S} / \mathrm{S}+\mathrm{E}) \times 100$ where, $\mathrm{S}$ and $\mathrm{E}$ are the number of stomata per unit area and number of 
epidermal cells per unit area, respectively in microscopic view field and the values were expressed in percentage (\%). Morphometric measurements for different cells (long cells, stomatal cells, epidermal cells) were taken under suitable magnification by using calibrated ocular micrometer.

Statistical analysis

A statistical comparison of means of different accessions and leaf epidermal quantitative characters was carried out by analysis of variance (ANOVA) followed by Duncun's Multiple Range Test (DMRT). Significance level was set at $\mathrm{p}<0.05$. The data analysis was done using SPSS version 20.0 for Windows. Graphs were drawn by Microsoft Office Excel software.

\section{Results and Discussion}

\section{Qualitative leaf epidermal characters}

Under this sub-head the findings are described and discussed based on Table 1, Figs. 1A-C (a$\mathrm{x})$, and $2 \mathrm{~A}-\mathrm{C}(\mathrm{a}-\mathrm{x})$. The leaves were found to be amphistomatic. The stomata were paracytic type, dumbbell shaped with two subsidiary cells placed parallel to the pore. Two guard cells were found with two subsidiary cells lateral to the guard cells. Subsidiary cells in $C$. dactylon were found to be dome shaped at both abaxial and adaxial surface of the leaves. Hepworth et al. (2018) reported, amphistomatic leaves with dumbbell-like, aligned stomata as usual in grass species. Like almost all grasses stomata in $C$. dactylon are paracytic type earlier proved by Abid et al. (2007). Due to disposition of the subsidiary cells, the stomata were markedly paracytic, which is also typical of Poaceae family (Rudall et al., 2017). Stomatal shape was more responsive to salt stress in the salt range population where elliptic stomatal complex transform to rhomboid and smaller ones under high salt stress (Hameed et al., 2014), supports the present findings in case of the accessions collected from three coastal areas (Barguna, Cox's Bazar and St. Martin's Island) of Bangladesh.

The epidermal cells were elongated and arranged in vertical rows parallel to the long axis of the leaf. All epidermal cells in $C$. dactylon were found to be sinuous. Almost all epidermal cells in C. dactylon are found sinuous or wavy similar to the findings of Ahmed et al. (2010). Cynodon dactylon accessions had epidermal cells with sinuous cell walls, a common feature among species belonging to the Poaceae family (Khan et al., 2017) and which is related to the increase of the surface for higher light uptake (De Castro et al., 2009).

Length and width of long cells are significant parameters which help in identification and classification of grasses (Elahi and Ashraf, 2002). The long cell margins were found to show sinuous almost in all the accessions. But, in case of the accessions of Barguna, Cox's Bazar and St. Martin's Island, the long cell margins were found to be slightly sinuous. Silica bodies were saddle shaped and found in the materials collected from Rangpur, Lalmonirhat, Dinajpur, Thakurgaon, Panchagarh, Gaibandha, Rajshahi, Naogaon, Gazipur, Jhenaidah. Cross shaped silica bodies were found in materials of Pabna, Sherpur, Mymensingh, Khulna, Shariatpur, Khagrachari, Bandarban and Rangamati. Both saddle and cross shaped silica bodies were found in case of Narsingdi, Jessore and Faridpur. Horizontally elongated shaped silica bodies were found in case of samples collected from Barguna, Cox's Bazar and St. Martin's Island. Silica bodies are a type of phytolith in specialized epidermal cells of grass leaves. Various workers have considered silica bodies to be diagnostic for the family Poaceae (Twiss et al., 1969; Brown, 1984; Mulholland, 1989). Piperno and Pearsall (1998) studied the silica bodies of Tropical American grasses and discussed their taxonomic implications. Thomasson et al. (1986) noted that micro-morphological characters of the leaf provided information on the fossils phylogeny and taxonomic relationships. According to Metclafe (1960), Chaudhary et al. (2001a), and Ahmed (2009) silica bodies in $C$. dactylon are saddle shaped, which were again confirmed by the present research. 
Table 1. Qualitative leaf epidermal characteristics on both abaxial and adaxial surfaces of Cynodon dactylon (L.) Pers. collected from different habitats of Bangladesh.

\begin{tabular}{|c|c|c|c|c|c|c|c|c|c|}
\hline $\begin{array}{l}\text { Sl. } \\
\text { No. }\end{array}$ & Habitats & $\begin{array}{l}\text { Stomata } \\
\text { type }\end{array}$ & $\begin{array}{l}\text { Shape of } \\
\text { subsidiary } \\
\text { cells }\end{array}$ & $\begin{array}{l}\text { Long cell } \\
\text { margins }\end{array}$ & $\begin{array}{l}\text { Types of } \\
\text { silica bodies }\end{array}$ & $\begin{array}{c}\text { Macro } \\
\text { hair }\end{array}$ & $\begin{array}{l}\text { Micro } \\
\text { hair }\end{array}$ & $\begin{array}{l}\text { Prickle } \\
\text { angular }\end{array}$ & Hook \\
\hline 1 & Rangpur & Paracytic & Dome & Sinuous & Saddle & + & - & + & + \\
\hline 2 & Lalmonirhat & Paracytic & Dome & Sinuous & Saddle & + & - & + & + \\
\hline 3 & Dinajpur & Paracytic & Dome & Sinuous & Saddle & + & - & + & + \\
\hline 4 & Thakurgaon & Paracytic & Dome & Sinuous & Saddle & + & - & + & + \\
\hline 5 & Panchagarh & Paracytic & Dome & Sinuous & Saddle & + & - & + & + \\
\hline 6 & Gaibandha & Paracytic & Dome & Sinuous & Saddle & + & - & + & + \\
\hline 7 & Rajshahi & Paracytic & Dome & Sinuous & Saddle & + & - & + & + \\
\hline 8 & Naogaon & Paracytic & Dome & Sinuous & Saddle & + & - & + & + \\
\hline 9 & Pabna & Paracytic & Dome & Sinuous & Cross & + & - & + & + \\
\hline 10 & Gazipur & Paracytic & Dome & Sinuous & Saddle & + & - & + & + \\
\hline 11 & Narsingdi & Paracytic & Dome & Sinuous & Saddle, Cross & + & - & + & + \\
\hline 12 & Sherpur & Paracytic & Dome & Sinuous & Cross & + & - & + & + \\
\hline 13 & Mymensingh & Paracytic & Dome & Sinuous & Cross & + & - & + & + \\
\hline 14 & Khulna & Paracytic & Dome & Sinuous & Cross & + & - & + & + \\
\hline 15 & Jessore & Paracytic & Dome & Sinuous & Saddle, Cross & + & - & + & + \\
\hline 16 & Jhenaidah & Paracytic & Dome & Sinuous & Saddle & + & - & + & + \\
\hline 17 & Faridpur & Paracytic & Dome & Sinuous & Saddle, Cross & + & - & + & + \\
\hline 18 & Shariatpur & Paracytic & Dome & Sinuous & Cross & + & - & + & + \\
\hline 19 & Barguna & Paracytic & Dome & $\begin{array}{l}\text { Slightly } \\
\text { sinuous }\end{array}$ & $\begin{array}{l}\text { Horizontally } \\
\text { elongated }\end{array}$ & + & - & - & - \\
\hline 20 & Khagrachari & Paracytic & Dome & Sinuous & Cross & + & - & + & + \\
\hline 21 & Bandarban & Paracytic & Dome & Sinuous & Cross & + & - & + & + \\
\hline 22 & Rangamati & Paracytic & Dome & Sinuous & Cross & + & - & + & + \\
\hline 23 & Cox's Bazar & Paracytic & Dome & $\begin{array}{l}\text { Slightly } \\
\text { sinuous }\end{array}$ & $\begin{array}{l}\text { Horizontally } \\
\text { elongated }\end{array}$ & + & - & - & - \\
\hline 24 & $\begin{array}{l}\text { St. Martin's } \\
\text { Island }\end{array}$ & Paracytic & Dome & $\begin{array}{l}\text { Slightly } \\
\text { sinuous }\end{array}$ & $\begin{array}{l}\text { Horizontally } \\
\text { elongated }\end{array}$ & + & - & - & - \\
\hline
\end{tabular}

$+=$ Present, - = Absent.

Prickles angular were pointed at the tip and they were present in almost all accessions except those from Barguna, Cox's Bazar and St. Martin's Island. Hooks were also present in almost all the accessions except from those materials of Barguna, Cox's Bazar and St. Martin's Island. Macro-hairs were present in all accessions. No micro-hair was found in adaxially or abaxially in this present study. Chaudhary et al. (2001b) found that in C. dactylon, stomata were with triangular subsidiary cells, silica bodies were saddle shaped, and micro-hairs with hemispherical distal cells, while macro-hairs were absent. Freire et al. (2005) observed the presence of micro hairs in $C$. dactylon. In the current study, an opposite result has been observes, macro hair was present but micro hair was absent. These features were similar to the results of Prat $(1934,1961)$, Metcalfe (1960), Ahmad (2009), and Khan et al. (2017). It may be due to environmental variations as $C$. dactylon is a wide spreading grass, which varies considerably in habit. Ishtiaq et al. (2018) also found that micro-hair was absent in $C$. dactylon. In the present investigation, $C$. dactylon showed dome shaped subsidiary cells at both abaxial and adaxial surface of the leaves. 

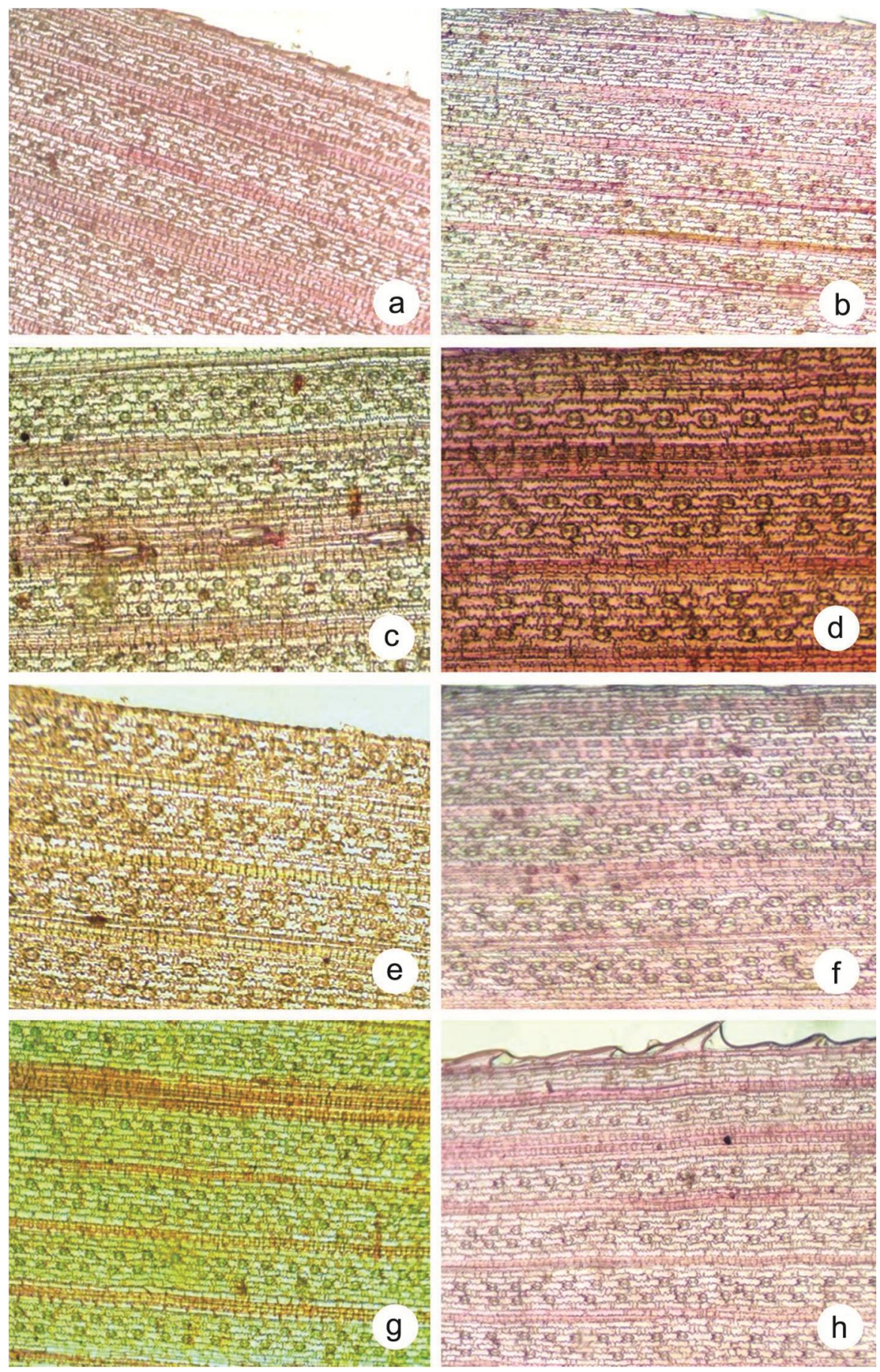

Fig. 1A (a-h): Foliar epidermal structure on abaxial surface of $C$. dactylon accessions collected from different habitats; a) Rangpur, b) Lalmonirhat, c) Dinajpur, d) Thakurgaon, e) Panchagarh, f) Gaibandha, g) Rajshahi, h) Naogaon. 

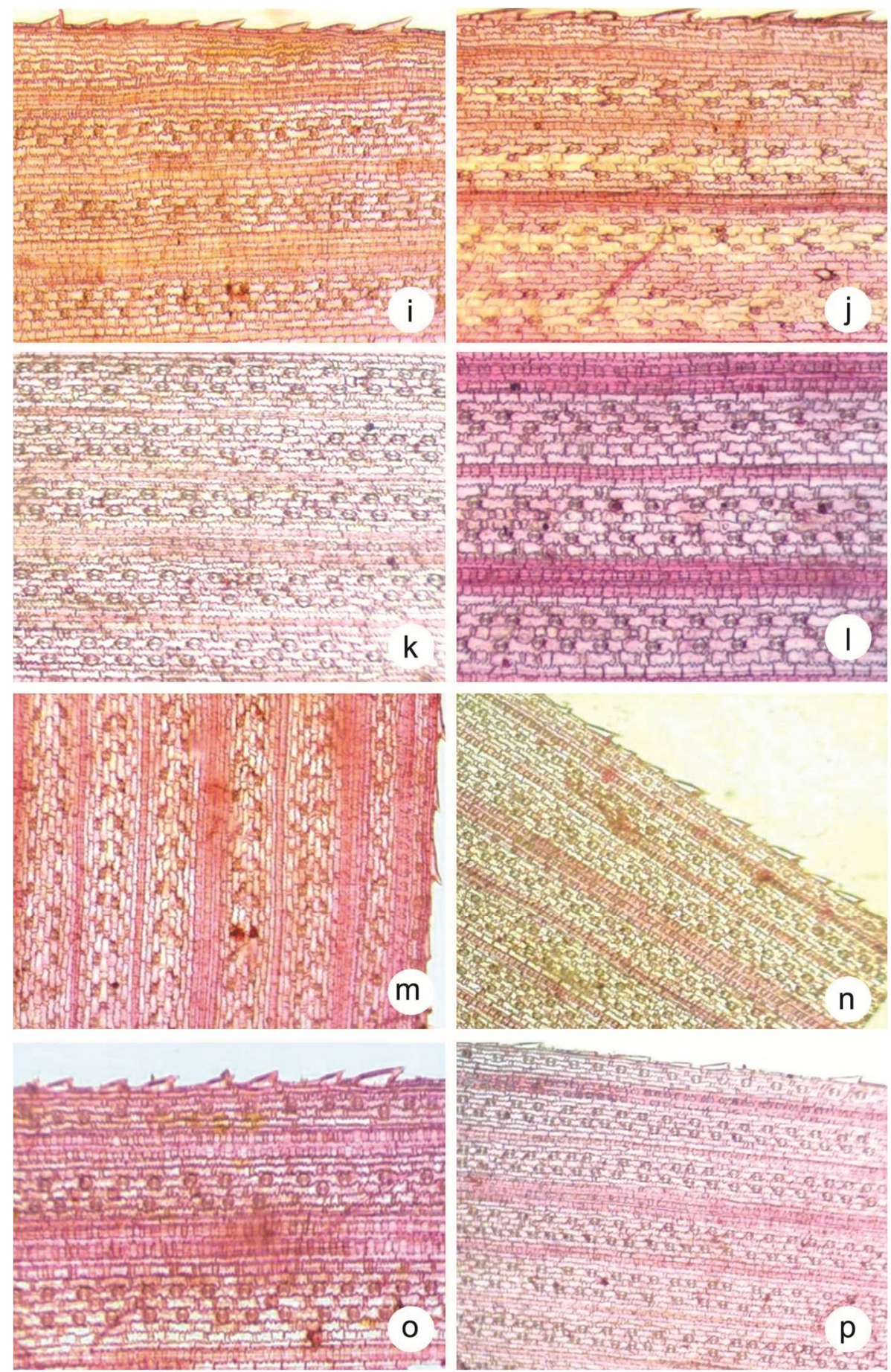

Fig. 1B (i-p): Foliar epidermal structure on abaxial surface of $C$. dactylon accessions collected from different habitats; i) Pabna, j) Gazipur, k) Narsingdi, 1) Sherpur, m) Mymensingh, n) Khulna, o) Jessore, p) Jhenaidah. 

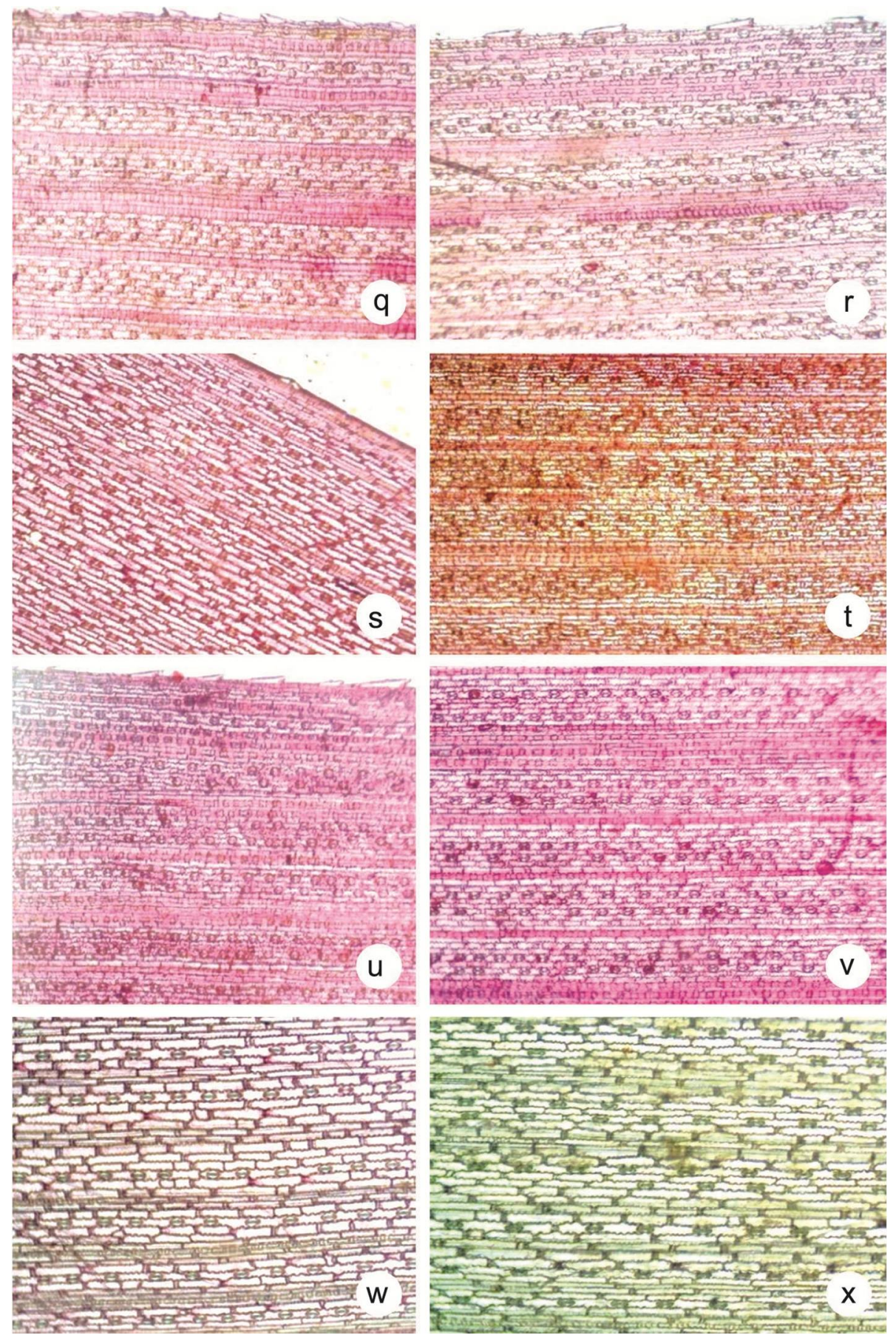

Fig. 1C (q-x): Foliar epidermal structure on abaxial surface of $C$. dactylon accessions collected from different habitats; q) Faridpur, r) Shariatpur, s) Barguna, t) Khagrachari, u) Bandarban, v) Rangamati, w) Cox's Bazar, x) Saint Martin's Island. 
Quantitative leaf epidermal characters

Under this subhead the findings are described and discussed based on the Figs. 1A-C (a-x) and 2A-C (a-x) and the values are shown in Tables 2-9. For abaxial surface of the leaves, highest mean value for long cell numbers per $\mathrm{mm}^{2}$ was found in sample collected from Khulna (7.72) and lowest value was found in case of St. Martin's Island (2.14) (Table 2). In adaxial surface of the leaves highest mean value for long cell numbers per $\mathrm{mm}^{2}$ was found in sample collected from Shariatpur (9.65) and lowest value was found in Barguna (3.31) (Table 6). The mean value of long cell length was highest in case of samples collected from St. Martin's Island $(110.26 \mu \mathrm{m})$ and lowest in case of Cox's Bazar $(32.20 \mu \mathrm{m})$ in abaxial surface of the leaves (Table 2). Long cell length was highest in case of Barguna $(90.76 \mu \mathrm{m})$ and lowest in case of Shariatpur $(31.39 \mu \mathrm{m})$ in adaxial surface of the leaves (Table 6). The mean long cell width was found to be highest in sample of St. Martin's Island $(8.82 \mu \mathrm{m})$ and lowest in sample of Cox's Bazar $(4.03 \mu \mathrm{m})$ in abaxial surface the leaves (Table 2). Long cell width was highest in Cox's Bazar $(12.33 \mu \mathrm{m})$ and lowest in Rangamati $(3.40 \mu \mathrm{m})$ in adaxial surface of the leaves (Table 6). The variations regarding different parameters in case of long cells might be due to variations of environmental behavior such as water stress and changes in temperature.

Stomatal frequency was highest in sample of Gazipur $\left(5.56 \mathrm{~mm}^{-2}\right)$ and lowest in sample of St. Martin's Island $\left(1.78 \mathrm{~mm}^{-2}\right)$ in abaxial surfaces of the leaves (Table 3). Stomatal frequency was highest in case of Shariatpur $\left(6.61 \mathrm{~mm}^{-2}\right)$ and lowest in case of Barguna $\left(3.02 \mathrm{~mm}^{-2}\right)$ in adaxial surfaces of the leaves (Table 7). Leaf morphological characters like stomatal frequency, distribution, and epidermal features may affect gas exchange quite remarkably and their relationships with key environmental factors such as light, water status, and $\mathrm{CO}_{2}$ levels have been found to respond to changing environmental variables of temperature, rainfall, irradiance and $\mathrm{CO}_{2}$ (Beeling, 1995; Royer et al., 2001). Therefore, they mainly contribute to the ability of plants to control their water relations and to gain carbon (Hetherington and Woodward, 2003). It has been shown that environmental signals such as light intensity, carbon dioxide concentration and water availability may affect stomatal development by modifying their size and frequency (Knapp et al., 1994; Dyki et al., 1998). Therefore, it is possible that variations in stomatal characteristics may influence plant growth and productivity (Kundu and Tigerstedt, 1998). Reduction in stomatal frequency and size might also be an efficient feature of checking under water loss via transpiration during limited water availability and under high salinities as reported by different researchers (Walsh, 1990; Bray and Reid, 2002). The salt range ecotype showed decreased stomatal area and frequency under saline conditions on the adaxial leaf surface, so due to this it can be regarded as the best adapted ecotype against highly saline environments.

Intrinsic variation is a factor that may obscure the potential use of stomatal frequency as a paleoclimatalogical tool (Wagner et al., 2005). In terms of stomatal frequency intrinsic variation is the variability in stomatal distribution across a leaf surfaces (Poole and Kurshner, 1999) and has the potential to be large in angiosperms (Uhl and Kerp, 2005). The reality of reduced stomatal conductance as a response to increased $\mathrm{CO}_{2}$ has been inferred from measurements of transpiration rates during $\mathrm{CO}_{2}$-doubling experiments with agricultural species as well as tree seedlings. An increasing $\mathrm{CO}_{2}$ concentration often leads to a significant decrease in leaf conductance corresponding with an increase in water-use efficiency (Eamus, 1991). These parameters are helpful to differentiate the species. However, the stomatal features may prove to be a little taxonomic value unless the developments of different stomata types were studied. A greater number of information on taxa will be helpful to understand the taxonomic value of stomata type and distribution. Beerling (1995), and McElwain and Chaloner (1995) have provided evidence that stomata frequency decline in response to increasing $\mathrm{CO}_{2}$ and may have occurred over geological 

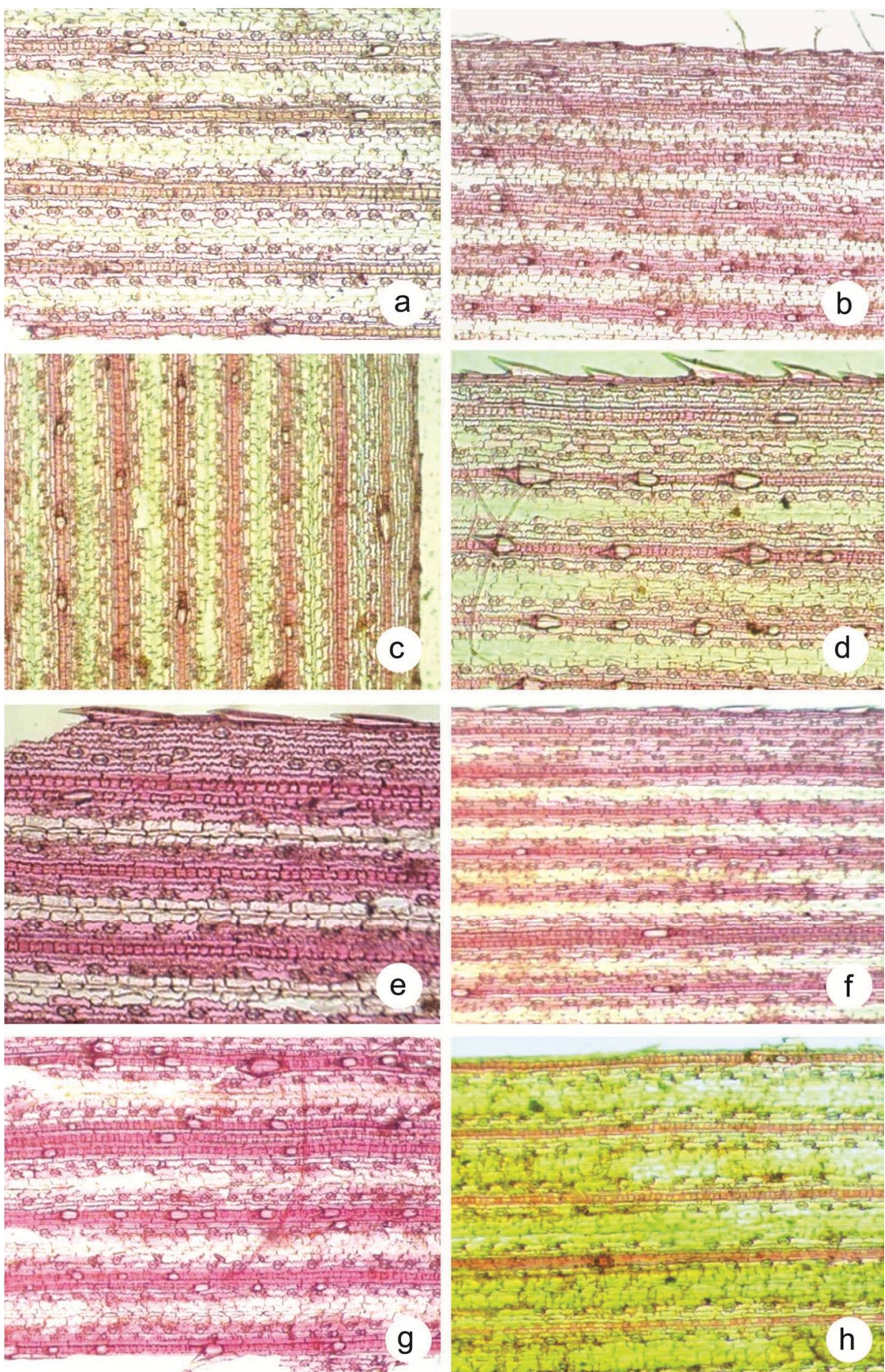

Fig. 2A (a-h): Foliar epidermal structure on adaxial surface of $C$. dactylon accessions collected from different habitats; a) Rangpur, b) Lalmonirhat, c) Dinajpur, d) Thakurgaon, e) Panchagarh, f) Gaibandha, g) Rajshahi, h) Naogaon. 

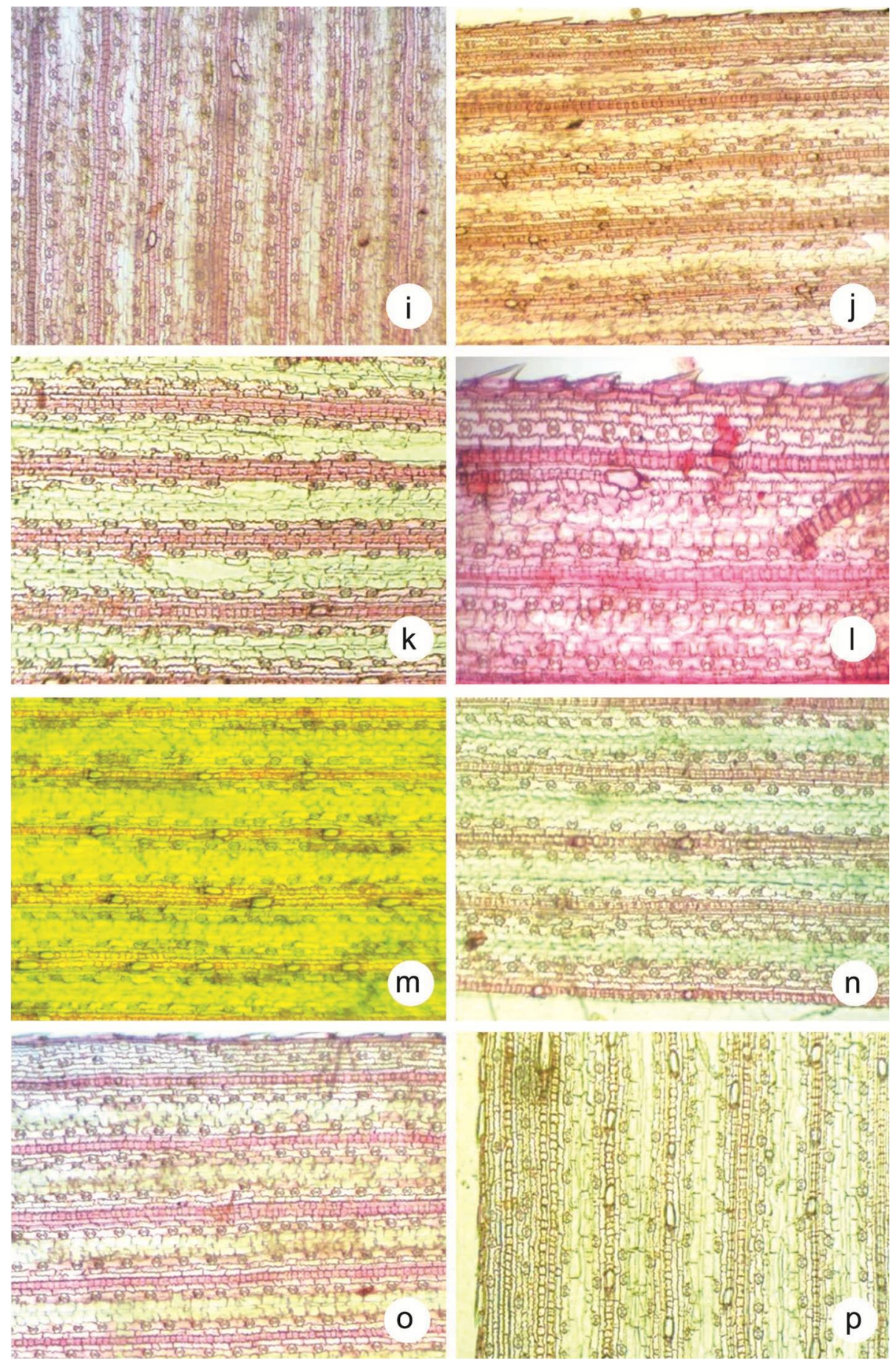

Fig. 2B (i-p): Foliar epidermal structure on adaxial surface of $C$. dactylon accessions collected from different habitats; i) Pabna, j) Gazipur, k) Narsingdi, l) Sherpur, m) Mymensingh, n) Khulna, o) Jessore, p) Jhenaidah. 

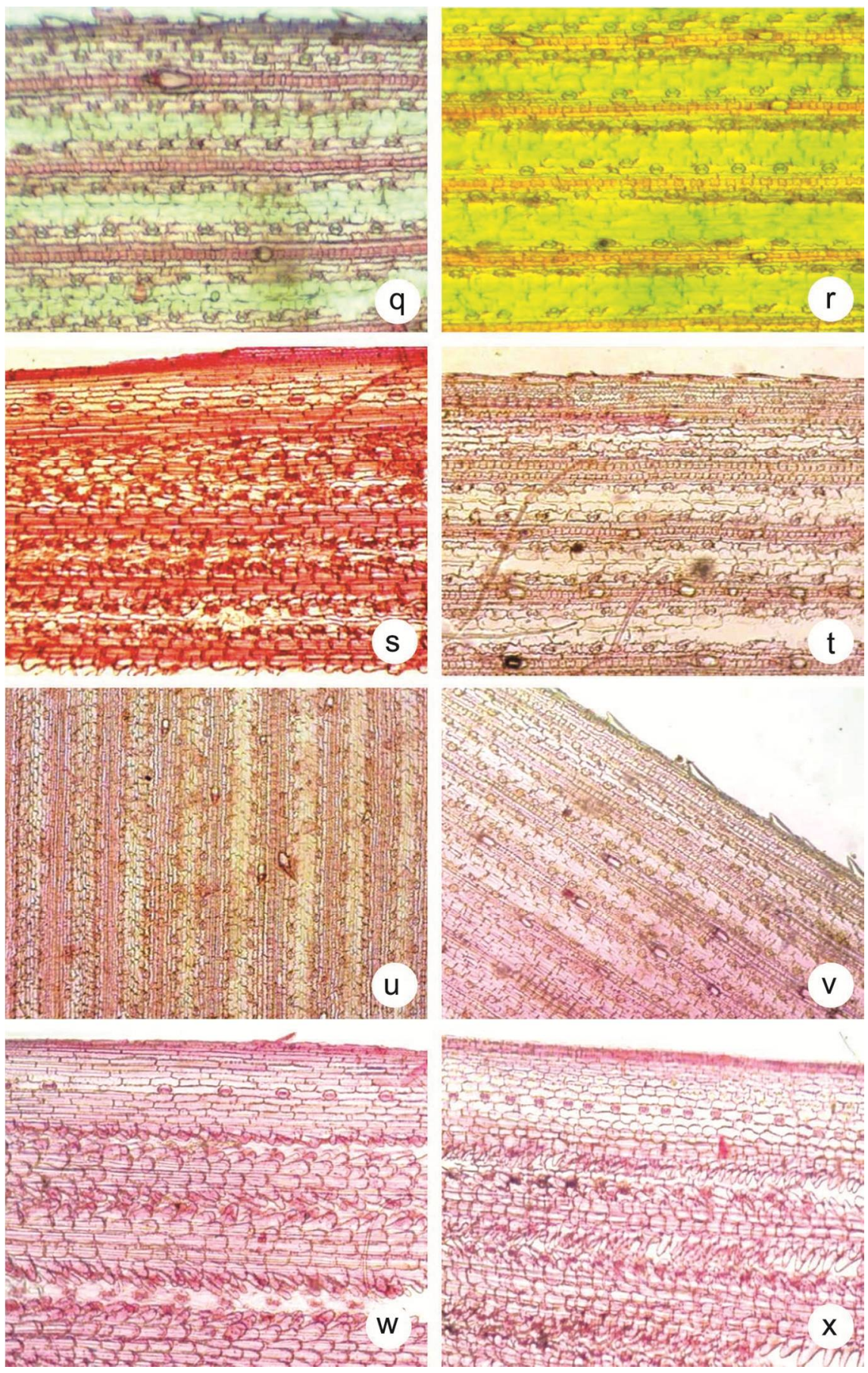

Fig. 2C (q-x): Foliar epidermal structure on adaxial surface of $C$. dactylon accessions collected from different habitats; q) Faridpur, r) Shariatpur, s) Barguna, t) Khagrachari, u) Bandarban, v) Rangamati, w) Cox's Bazar, x) Saint Martin's Island. 
time. Stomatal frequency in present day can be estimated by growing them at different $\mathrm{CO}_{2}$ concentration (Vesque, 1989).

Epidermal cell number per $\mathrm{mm}^{2}$ was highest in case of Gaibandha (23.89) and lowest in case of St. Martin's Island (4.5) in abaxial surface of the leaves (Table 3). Epidermal cell number per $\mathrm{mm}^{2}$ was highest in case of Shariatpur (19.99) and lowest in case of Barguna (9.28) in adaxial surface of the leaves (Table 7). Fernandez and Mujica (1973) determined that an increase in light intensity decreased the epidermal cell number and increased the stomatal number index and size. Schoch et al. (1984) reported that blue and far-red light reduced the stomatal index while red light increased this stomatal index. Kim et al. (2004) showed that blue and red light increased the stomata size and decreased the stomata number. Lee et al. (2007) found that white light increased the stomatal number and size, while blue light reduced the mentioned parameters.

Table 2. Quantitative epidermal characteristics on abaxial surface of leaves of Cynodon dactylon collected from different habitats of Bangladesh.

\begin{tabular}{|c|c|c|c|c|}
\hline $\begin{array}{l}\text { Sl. } \\
\text { No. }\end{array}$ & Habitats & Long cells $/ \mathrm{mm}^{2}$ & $\begin{array}{l}\text { Long cell length } \\
(\mu \mathrm{m})\end{array}$ & $\begin{array}{l}\text { Long cell width } \\
(\mu \mathrm{m})\end{array}$ \\
\hline 1 & Rangpur & $7.66 \pm 0.15 \mathrm{~cd}$ & $33.91 \pm 2.39 \mathrm{hi}$ & $6.43 \pm 0.26 \mathrm{abcd}$ \\
\hline 2 & Lalmonirhat & $5.69 \pm 0.13 \mathrm{hijk}$ & $42.95 \pm 2.39 \mathrm{efg}$ & $6.42 \pm 0.17 \mathrm{abcd}$ \\
\hline 3 & Dinajpur & $5.76 \pm 0.10$ ghij & $32.29 \pm 2.26 \mathrm{i}$ & $8.02 \pm 0.17 \mathrm{ab}$ \\
\hline 4 & Thakurgaon & $4.75 \pm 0.08 \mathrm{~m}$ & $40.29 \pm 2.30 \mathrm{efgh}$ & $8.02 \pm 0.22 \mathrm{a}$ \\
\hline 5 & Panchagarh & $5.17 \pm 0.13 \mathrm{jklm}$ & $42.29 \pm 2.26 \mathrm{efg}$ & $8.03 \pm 0.26 a b$ \\
\hline 6 & Gaibandha & $6.19 \pm 0.08$ efghi & $39.94 \pm 1.61 \mathrm{efgh}$ & $8.02 \pm 0.13 a b c$ \\
\hline 7 & Rajshahi & $5.16 \pm 0.10 \mathrm{jklm}$ & $39.86 \pm 2.00 \mathrm{efgh}$ & $6.69 \pm 0.13 \mathrm{abcd}$ \\
\hline 8 & Naogaon & $7.07 \pm 0.08 b c$ & $40.20 \pm 1.56 \mathrm{efgh}$ & $6.42 \pm 0.17 \mathrm{abcd}$ \\
\hline 9 & Pabna & $5.56 \pm 0.10 \mathrm{ijkl}$ & $38.88 \pm 1.65$ fghi & $8.03 \pm 0.26 \mathrm{abcd}$ \\
\hline 10 & Gazipur & $7.09 \pm 0.13 b c$ & $44.29 \pm 2.30 \mathrm{def}$ & $4.43 \pm 0.22 \mathrm{~cd}$ \\
\hline 11 & Narsingdi & $5.01 \pm 0.131 \mathrm{~m}$ & $40.23 \pm 1.78 \mathrm{efgh}$ & $8.02 \pm 0.17 \mathrm{abc}$ \\
\hline 12 & Sherpur & $6.37 \pm 0.13 \mathrm{defg}$ & $40.37 \pm 1.61 \mathrm{efgh}$ & $7.02 \pm 0.13 \mathrm{abcd}$ \\
\hline 13 & Mymensingh & $5.10 \pm 0.15 \mathrm{klm}$ & $32.95 \pm 2.21 \mathrm{i}$ & $7.70 \pm 0.13 \mathrm{abcd}$ \\
\hline 14 & Khulna & $7.72 \pm 0.10 \mathrm{a}$ & $58.90 \pm 2.00 \mathrm{c}$ & $6.82 \pm 0.13 \mathrm{abcd}$ \\
\hline 15 & Jessore & $6.09 \pm 0.13$ fghi & $49.63 \pm 2.30 \mathrm{~d}$ & $7.22 \pm 0.13 \mathrm{abcd}$ \\
\hline 16 & Jhenaidah & $6.61 \pm 0.13 \mathrm{cdef}$ & $37.64 \pm 2.34 \mathrm{ghi}$ & $4.83 \pm 0.22 \mathrm{~d}$ \\
\hline 17 & Faridpur & $5.04 \pm 0.10 \mathrm{klm}$ & $37.02 \pm 1.74 \mathrm{ghi}$ & $6.17 \pm 0.26 \mathrm{abcd}$ \\
\hline 18 & Shariatpur & $6.01 \pm 0.13$ fghi & $45.87 \pm 2.08 \mathrm{de}$ & $8.03 \pm 0.26 \mathrm{a}$ \\
\hline 19 & Barguna & $2.57 \pm 0.13 n$ & $96.28 \pm 2.17 b$ & $8.43 \pm 0.26 a b$ \\
\hline 20 & Khagrachari & $7.62 \pm 0.15 \mathrm{ab}$ & $33.59 \pm 2.00 \mathrm{hi}$ & $7.48 \pm 0.13 \mathrm{abcd}$ \\
\hline 21 & Bandarban & $6.32 \pm 0.10 \mathrm{efgh}$ & $34.31 \pm 2.43 \mathrm{hi}$ & $6.68 \pm 0.13 \mathrm{abcd}$ \\
\hline 22 & Rangamati & $6.81 \pm 0.13 \mathrm{cde}$ & $34.22 \pm 1.69 \mathrm{hi}$ & $6.70 \pm 0.26 \mathrm{bcd}$ \\
\hline 23 & Cox's Bazar & $2.47 \pm 0.08 n$ & $32.20 \pm 1.56 \mathrm{i}$ & $4.03 \pm 0.22 \mathrm{~cd}$ \\
\hline 24 & St. Martin's Island & $2.14 \pm 0.15 n$ & $110.26 \pm 2.00 \mathrm{a}$ & $8.82 \pm 0.17 \mathrm{a}$ \\
\hline
\end{tabular}

$\mathrm{SE}=$ Standard error, $\mathrm{n}=24$. In the column, mean values bearing similar letter(s) or without letter are identical and those having dissimilar letters are differed significantly as per Duncan's Multiple Range Test. 
Table 3. Quantitative epidermal characteristics on abaxial surface of leaves of Cynodon dactylon collected from different habitats of Bangladesh.

\begin{tabular}{|c|c|c|c|c|}
\hline $\begin{array}{l}\text { Sl. } \\
\text { No. }\end{array}$ & Habitats & $\begin{array}{l}\text { Stomatal } \\
\text { frequency }\end{array}$ & $\begin{array}{l}\text { Epidermal cell no. } \\
/ \mathrm{mm}^{2}\end{array}$ & Stomatal index \\
\hline 1 & Rangpur & $4.52 \pm 0.10$ fghi & $11.92 \pm 0.95 \mathrm{cdef}$ & $26.36 \pm 0.49 \mathrm{ab}$ \\
\hline 2 & Lalmonirhat & $4.59 \pm 0.08 \mathrm{efgh}$ & $13.28 \pm 0.91$ bcdef & $26.34 \pm 0.62 \mathrm{ab}$ \\
\hline 3 & Dinajpur & $4.82 \pm 0.15 \mathrm{cdef}$ & $12.61 \pm 1.30 \mathrm{cdef}$ & $26.47 \pm 0.36 \mathrm{ab}$ \\
\hline 4 & Thakurgaon & $3.71 \pm 0.08 \mathrm{k}$ & $10.81 \pm 1.30 \mathrm{ef}$ & $25.46 \pm 0.32 \mathrm{ab}$ \\
\hline 5 & Panchagarh & $4.26 \pm 0.15 \mathrm{hij}$ & $9.60 \pm 1.21 \mathrm{f}$ & $28.00 \pm 0.91 \mathrm{ab}$ \\
\hline 6 & Gaibandha & $4.29 \pm 0.13 \mathrm{hij}$ & $23.89 \pm 0.69 \mathrm{a}$ & $25.40 \pm 0.82 \mathrm{ab}$ \\
\hline 7 & Rajshahi & $4.03 \pm 0.08 \mathrm{jk}$ & $12.37 \pm 1.30 \mathrm{cdef}$ & $25.61 \pm 0.88 \mathrm{ab}$ \\
\hline 8 & Naogaon & $4.93 \pm 0.13 \mathrm{cde}$ & $12.59 \pm 1.48 \mathrm{cdef}$ & $26.40 \pm 0.61 \mathrm{ab}$ \\
\hline 9 & Pabna & $4.82 \pm 0.15 \mathrm{cdef}$ & $13.78 \pm 0.78 \mathrm{bcde}$ & $25.78 \pm 0.52 \mathrm{ab}$ \\
\hline 10 & Gazipur & $5.56 \pm 0.10 \mathrm{a}$ & $16.21 \pm 1.04 \mathrm{~b}$ & $25.80 \pm 0.61 \mathrm{ab}$ \\
\hline 11 & Narsingdi & $4.19 \pm 0.08 \mathrm{ij}$ & $11.33 \pm 1.35 \mathrm{def}$ & $26.25 \pm 0.30 \mathrm{ab}$ \\
\hline 12 & Sherpur & $4.32 \pm 0.10$ ghij & $13.29 \pm 1.30 \mathrm{bcdef}$ & $25.67 \pm 0.96 \mathrm{ab}$ \\
\hline 13 & Mymensingh & $4.77 \pm 0.13 \mathrm{cdef}$ & $10.61 \pm 1.04 \mathrm{ef}$ & $27.42 \pm 1.40 \mathrm{ab}$ \\
\hline 14 & Khulna & $5.40 \pm 0.10 \mathrm{ab}$ & $15.53 \pm 1.04 b c$ & $27.78 \pm 1.31 \mathrm{ab}$ \\
\hline 15 & Jessore & $5.06 \pm 0.15 \mathrm{bcd}$ & $10.48 \pm 0.65 \mathrm{ef}$ & $28.43 \pm 1.55 \mathrm{a}$ \\
\hline 16 & Jhenaidah & $4.83 \pm 0.08 \mathrm{cdef}$ & $13.63 \pm 1.17 \mathrm{bcde}$ & $25.36 \pm 0.30 b$ \\
\hline 17 & Faridpur & $4.68 \pm 0.10 \mathrm{defg}$ & $10.32 \pm 0.91 \mathrm{ef}$ & $27.64 \pm 1.51 \mathrm{ab}$ \\
\hline 18 & Shariatpur & $4.69 \pm 0.13 \mathrm{cdefg}$ & $11.06 \pm 1.08 \mathrm{ef}$ & $27.36 \pm 1.78 \mathrm{ab}$ \\
\hline 19 & Barguna & $2.13 \pm 0.131$ & $5.54 \pm 1.39 \mathrm{~g}$ & $26.26 \pm 0.43 \mathrm{ab}$ \\
\hline 20 & Khagrachari & $4.56 \pm 0.10$ efghi & $12.3 \pm 0.78 \mathrm{cdef}$ & $25.98 \pm 0.29 \mathrm{ab}$ \\
\hline 21 & Bandarban & $5.07 \pm 0.08 b c$ & $14.86 \pm 1.08 \mathrm{bcd}$ & $26.13 \pm 0.71 \mathrm{ab}$ \\
\hline 22 & Rangamati & $4.52 \pm 0.10$ fghi & $12.98 \pm 1.39 \mathrm{bcdef}$ & $26.17 \pm 0.56 \mathrm{ab}$ \\
\hline 23 & Cox's Bazar & $2.13 \pm 0.131$ & $5.56 \pm 1.56 \mathrm{~g}$ & $26.31 \pm 0.30 \mathrm{ab}$ \\
\hline 24 & St. Martin's Island & $1.78 \pm 0.15 \mathrm{~m}$ & $4.5 \pm 0.78 \mathrm{~g}$ & $26.59 \pm 0.78 \mathrm{ab}$ \\
\hline
\end{tabular}

$\mathrm{SE}=$ Standard error, $\mathrm{n}=24$. In the column, mean values bearing similar letter(s) or without letter are identical and those having dissimilar letters are differed significantly as per Duncan's Multiple Range Test.

Stomatal index was highest in Jessore (28.43\%) and lowest in Jhenaidah (25.36\%) for abaxial surface of the leaves (Table 3). Stomatal index was highest in Khulna (28.76\%) and lowest in Jhenaidah (24.97\%) in adaxial surface of the leaves (Table 7). Stomatal length with guard cell was highest in sample of Cox's Bazar $(21.50 \mu \mathrm{m})$ and lowest in case of Mymensingh $(11.50 \mu \mathrm{m})$ in abaxial surface of the leaves (Table 4). Stomatal length with guard cell was highest in case of St. Martin's Island $(17.59 \mu \mathrm{m})$ and lowest in case of Mymensingh $(11.56 \mu \mathrm{m})$ in adaxial surface of the leaves (Table 8). Stomatal breadth with guard cell was highest in sample of St. Martin's Island $(13.71 \mu \mathrm{m})$ and lowest in Khulna $(8.11 \mu \mathrm{m})$ in abaxial surface of the leaves (Table 4). Stomatal breadth with guard cell was highest in Barguna $(15.62 \mu \mathrm{m})$ and lowest in Khulna $(8.11 \mu \mathrm{m})$ in adaxial surface of the leaves (Table 8). Tufail et al. (2017) observed stomata with small dimensions in ecotype of $C$. dactylon, which could be related to a more efficient physiological regulation since less turgor is required for the opening and closing of the ostiole. It reinforces what 
had been previously reported in fossils of species belonging to several families, including Poaceae (Franks and Beerling, 2009) along with different plant species in which higher stomatal densities mediated by small sized stomata provide enhanced conductivity and higher photosynthesis rates (Franks et al. 2009; Drake et al. 2013; Vrablova et al., 2017). Nevertheless, Hetherington and Woodward (2003) pointed out that when the environmental alterations are unfavorable the conductance of small stomata is quickly reduced. Carpenter and Smith (1975) had established such a relationship involving stomata size and growth habit. Xerophytic species have much smaller stomata than mesophytic species. It may be compensating for the presence of larger stomata and it may be associated with adaptive success of polyploids (Van De Peer et al., 2017), mainly regarding water stress and changes in temperature (Simonneau et al., 2017).

Table 4. Quantitative epidermal characteristics on abaxial surface of leaves of Cynodon dactylon collected from different habitats of Bangladesh.

\begin{tabular}{|c|c|c|c|c|c|}
\hline $\begin{array}{l}\text { Sl. } \\
\text { No. }\end{array}$ & Habitats & $\begin{array}{l}\text { Stomata length with } \\
\text { guard cell }(\mu \mathrm{m})\end{array}$ & $\begin{array}{l}\text { Stomata breadth } \\
\text { with guard cell } \\
(\mu \mathrm{m})\end{array}$ & $\begin{array}{l}\text { Epidermal cell } \\
\text { length }(\mu \mathrm{m})\end{array}$ & $\begin{array}{l}\text { Epidermal cell } \\
\text { breadth }(\mu \mathrm{m})\end{array}$ \\
\hline 1 & Rangpur & $12.82 \pm 0.66 f$ & $9.11 \pm 0.87 \mathrm{~cd}$ & $32.12 \pm 0.95 \mathrm{~h}$ & $8.14 \pm 1.13 \mathrm{~cd}$ \\
\hline 2 & Lalmonirhat & $16.39 \pm 0.33 \mathrm{~cd}$ & $9.48 \pm 1.13 \mathrm{bcd}$ & $35.06 \pm 0.95 \mathrm{fg}$ & $8.41 \pm 1.13 \mathrm{~cd}$ \\
\hline 3 & Dinajpur & $16.75 \pm 0.38 \mathrm{c}$ & $8.26 \pm 0.43 \mathrm{~d}$ & $38.12 \pm 0.95 \mathrm{de}$ & $8.09 \pm 0.74 \mathrm{~cd}$ \\
\hline 4 & Thakurgaon & $15.75 \pm 0.28 \mathrm{cde}$ & $9.07 \pm 0.87 \mathrm{~cd}$ & $32.13 \pm 1.00 \mathrm{~h}$ & $8.10 \pm 0.78 \mathrm{~cd}$ \\
\hline 5 & Panchagarh & $16.12 \pm 0.59 \mathrm{cde}$ & $9.38 \pm 0.78 \mathrm{bcd}$ & $39.29 \pm 0.74 d$ & $10.12 \pm 0.95 \mathrm{c}$ \\
\hline 6 & Gaibandha & $15.60 \pm 0.51 \mathrm{cde}$ & $9.02 \pm 0.48 \mathrm{~cd}$ & $36.10 \pm 0.78 \mathrm{ef}$ & $9.73 \pm 1.04 \mathrm{~cd}$ \\
\hline 7 & Rajshahi & $15.86 \pm 0.66 \mathrm{e}$ & $8.22 \pm 0.43 \mathrm{~d}$ & $24.06 \pm 0.43 \mathrm{k}$ & $8.06 \pm 0.43 \mathrm{~cd}$ \\
\hline 8 & Naogaon & $16.05 \pm 0.64 \mathrm{cde}$ & $9.37 \pm 0.69 \mathrm{bcd}$ & $36.07 \pm 0.56 \mathrm{ef}$ & $8.10 \pm 0.78 \mathrm{~cd}$ \\
\hline 9 & Pabna & $15.95 \pm 0.38 \mathrm{cde}$ & $9.58 \pm 1.13 \mathrm{bcd}$ & $36.07 \pm 0.52 \mathrm{ef}$ & $8.07 \pm 0.56 \mathrm{~cd}$ \\
\hline 10 & Gazipur & $15.70 \pm 0.66 \mathrm{e}$ & $10.66 \pm 0.43 \mathrm{bcd}$ & $38.75 \pm 0.87 d$ & $7.79 \pm 0.43 \mathrm{~cd}$ \\
\hline 11 & Narsingdi & $16.30 \pm 0.56 \mathrm{cde}$ & $11.81 \pm 0.61 \mathrm{ab}$ & $29.41 \pm 0.56 \mathrm{i}$ & $8.06 \pm 0.43 \mathrm{~cd}$ \\
\hline 12 & Sherpur & $12.57 \pm 0.53 f$ & $8.61 \pm 1.00 \mathrm{~cd}$ & $34.85 \pm 1.04 \mathrm{fg}$ & $8.23 \pm 0.52 \mathrm{~cd}$ \\
\hline 13 & Mymensingh & $11.50 \pm 0.46 f$ & $10.40 \pm 1.04 \mathrm{bcd}$ & $33.32 \pm 0.95 \mathrm{gh}$ & $8.14 \pm 1.13 \mathrm{~cd}$ \\
\hline 14 & Khulna & $14.95 \pm 0.28 \mathrm{e}$ & $8.11 \pm 0.87 \mathrm{~d}$ & $27.00 \pm 0.48 \mathrm{j}$ & $7.31 \pm 0.82 \mathrm{~d}$ \\
\hline 15 & Jessore & $12.23 \pm 0.28 f$ & $8.14 \pm 1.08 \mathrm{~d}$ & $36.11 \pm 0.82 \mathrm{ef}$ & $8.14 \pm 1.08 \mathrm{~cd}$ \\
\hline 16 & Jhenaidah & $15.35 \pm 0.59 \mathrm{e}$ & $10.21 \pm 1.04 \mathrm{bcd}$ & $29.40 \pm 0.48 \mathrm{i}$ & $7.73 \pm 1.04 \mathrm{~cd}$ \\
\hline 17 & Faridpur & $15.87 \pm 0.59 \mathrm{de}$ & $8.14 \pm 1.08 \mathrm{~d}$ & $23.07 \pm 0.52 \mathrm{k}$ & $8.46 \pm 0.43 \mathrm{~cd}$ \\
\hline 18 & Shariatpur & $15.30 \pm 0.36 \mathrm{de}$ & $12.07 \pm 0.56 \mathrm{ab}$ & $28.12 \pm 0.91 \mathrm{ij}$ & $8.78 \pm 1.08 \mathrm{~cd}$ \\
\hline 19 & Barguna & $19.53 \pm 0.33 b$ & $9.83 \pm 0.56 \mathrm{bcd}$ & $72.25 \pm 0.61 b$ & $10.26 \pm 1.00 \mathrm{c}$ \\
\hline 20 & Khagrachari & $16.2 \pm 0.51 \mathrm{cde}$ & $8.86 \pm 0.48 \mathrm{~cd}$ & $40.08 \pm 0.61 d$ & $8.07 \pm 0.52 \mathrm{~cd}$ \\
\hline 21 & Bandarban & $14.79 \pm 0.33 \mathrm{e}$ & $8.12 \pm 0.91 d$ & $32.12 \pm 0.91 \mathrm{~h}$ & $8.09 \pm 0.69 \mathrm{~cd}$ \\
\hline 22 & Rangamati & $15.74 \pm 0.36 \mathrm{cde}$ & $8.93 \pm 1.04 \mathrm{~cd}$ & $26.07 \pm 0.52 j$ & $8.67 \pm 1.04 \mathrm{~cd}$ \\
\hline 23 & Cox's Bazar & $21.5 \pm 0.36 \mathrm{a}$ & $11.29 \pm 0.74 \mathrm{abc}$ & $70.09 \pm 0.69 \mathrm{c}$ & $21.74 \pm 1.13 \mathrm{a}$ \\
\hline 24 & St. Martin's Island & $20.63 \pm 0.48 \mathrm{ab}$ & $13.71 \pm 0.87 \mathrm{a}$ & $80.06 \pm 0.43 a$ & $16.25 \pm 0.91 b$ \\
\hline
\end{tabular}

$\mathrm{SE}=$ Standard error, $\mathrm{n}=24$. In the column, mean values bearing similar letter(s) or without letter are identical and those having dissimilar letters are differed significantly as per Duncan's Multiple Range Test. 
Table 5. Quantitative epidermal characteristics on abaxial surface of leaves of Cynodon dactylon collected from different habitats of Bangladesh.

\begin{tabular}{|c|c|c|c|c|c|}
\hline $\begin{array}{l}\text { Sl. } \\
\text { No. }\end{array}$ & Habitats & Silica bodies $/ \mathrm{mm}^{2}$ & $\begin{array}{l}\text { Prickles angular } \\
/ \mathrm{mm}^{2}\end{array}$ & Hooks $/ \mathrm{mm}^{2}$ & Macro hair $/ \mathrm{mm}^{2}$ \\
\hline 1 & Rangpur & $7.05 \pm 0.53 \mathrm{cdefgh}$ & $0.22 \pm 0.02 \mathrm{bcd}$ & $0.15 \pm 0.03 \mathrm{fgh}$ & $0.04 \pm 0.00 \mathrm{fg}$ \\
\hline 2 & Lalmonirhat & $5.28 \pm 0.31 \mathrm{gh}$ & $0.23 \pm 0.03 \mathrm{bcd}$ & $0.26 \pm 0.02 \mathrm{de}$ & $0.15 \pm 0.03 \mathrm{bcd}$ \\
\hline 3 & Dinajpur & $7.61 \pm 0.33 b c$ & $0.26 \pm 0.02 \mathrm{abcd}$ & $0.18 \pm 0.02 f g$ & $0.14 \pm 0.02 \mathrm{bcde}$ \\
\hline 4 & Thakurgaon & $5.79 \pm 0.38 \mathrm{gh}$ & $0.22 \pm 0.02 \mathrm{bcd}$ & $0.02 \pm 0.02 \mathrm{jk}$ & $0.09 \pm 0.01 \mathrm{cdefg}$ \\
\hline 5 & Panchagarh & $5.01 \pm 0.33 \mathrm{~h}$ & $0.29 \pm 0.01 \mathrm{ab}$ & $0.28 \pm 0.04 \mathrm{~cd}$ & $0.07 \pm 0.03 \mathrm{defg}$ \\
\hline 6 & Gaibandha & $6.66 \pm 0.46 \mathrm{efgh}$ & $0.32 \pm 0.04 \mathrm{a}$ & $0.04 \pm 0.00 \mathrm{ijk}$ & $0.14 \pm 0.02$ bcde \\
\hline 7 & Rajshahi & $6.45 \pm 0.43 \mathrm{fgh}$ & $0.26 \pm 0.02 \mathrm{abcd}$ & $0.96 \pm 0.04 \mathrm{a}$ & $0.10 \pm 0.02 \mathrm{bcdefg}$ \\
\hline 8 & Naogaon & $8.29 \pm 0.43 \mathrm{bcd}$ & $0.30 \pm 0.02 \mathrm{ab}$ & $0.43 \pm 0.03 b$ & $0.12 \pm 0.04$ bcdef \\
\hline 9 & Pabna & $7.24 \pm 0.61 \mathrm{bcdefg}$ & $0.22 \pm 0.02 \mathrm{bcd}$ & $0.29 \pm 0.01 \mathrm{~cd}$ & $0.10 \pm 0.02 \mathrm{bcdefg}$ \\
\hline 10 & Gazipur & $7.66 \pm 0.46 \mathrm{bcde}$ & $0.31 \pm 0.03 \mathrm{a}$ & $0.47 \pm 0.03 b$ & $0.06 \pm 0.02 \mathrm{efg}$ \\
\hline 11 & Narsingdi & $5.92 \pm 0.51 \mathrm{gh}$ & $0.26 \pm 0.02 \mathrm{abcd}$ & $0.31 \pm 0.03 \mathrm{~cd}$ & $0.10 \pm 0.02 \mathrm{cdefg}$ \\
\hline 12 & Sherpur & $7.01 \pm 0.64 \mathrm{efgh}$ & $0.23 \pm 0.03 \mathrm{bcd}$ & $0.02 \pm 0.02 \mathrm{jk}$ & $0.07 \pm 0.03 \mathrm{defg}$ \\
\hline 13 & Mymensingh & $6.39 \pm 0.38$ cdefgh & $0.19 \pm 0.03 \mathrm{~d}$ & $0.35 \pm 0.03 \mathrm{c}$ & $0.11 \pm 0.03$ bcdefg \\
\hline 14 & Khulna & $8.46 \pm 0.46 \mathrm{ab}$ & $0.31 \pm 0.03 a$ & $0.29 \pm 0.01 \mathrm{~cd}$ & $0.14 \pm 0.02 \mathrm{bcde}$ \\
\hline 15 & Jessore & $7.36 \pm 0.51 \mathrm{bcdef}$ & $0.23 \pm 0.03 \mathrm{bcd}$ & $0.16 \pm 0.00 \mathrm{fg}$ & $0.11 \pm 0.03$ bcdefg \\
\hline 16 & Jhenaidah & $7.17 \pm 0.64$ defgh & $0.28 \pm 0.00 \mathrm{abc}$ & $0.30 \pm 0.02 \mathrm{~cd}$ & $0.12 \pm 0.04 \mathrm{bcdef}$ \\
\hline 17 & Faridpur & $5.16 \pm 0.41 \mathrm{~h}$ & $0.23 \pm 0.03 \mathrm{bcd}$ & $0.11 \pm 0.03 \mathrm{ghi}$ & $0.09 \pm 0.01 \mathrm{cdefg}$ \\
\hline 18 & Shariatpur & $8.10 \pm 0.56 \mathrm{bcdef}$ & $0.20 \pm 0.00 \mathrm{~cd}$ & $0.18 \pm 0.02 f g$ & $0.18 \pm 0.02 b$ \\
\hline 19 & Barguna & $2.57 \pm 0.64 \mathrm{i}$ & $0.00 \pm 0.00 \mathrm{e}$ & $0.03 \pm 0.03 \mathrm{jk}$ & $0.10 \pm 0.02 \mathrm{cdefg}$ \\
\hline 20 & Khagrachari & $9.75 \pm 0.28 \mathrm{a}$ & $0.24 \pm 0.00 \mathrm{abcd}$ & $0.09 \pm 0.01 \mathrm{hij}$ & $0.02 \pm 0.02 \mathrm{~g}$ \\
\hline 21 & Bandarban & $10.26 \pm 0.66 \mathrm{a}$ & $0.27 \pm 0.03 \mathrm{abc}$ & $0.19 \pm 0.03 \mathrm{ef}$ & $0.07 \pm 0.03 \mathrm{defg}$ \\
\hline 22 & Rangamati & $8.87 \pm 0.59 \mathrm{ab}$ & $0.20 \pm 0.00 \mathrm{~cd}$ & $0.08 \pm 0.04 \mathrm{hijk}$ & $0.05 \pm 0.01 \mathrm{fg}$ \\
\hline 23 & Cox's Bazar & $2.92 \pm 0.61 \mathrm{i}$ & $0.00 \pm 0.00 \mathrm{e}$ & $0.00 \pm 0.00 \mathrm{k}$ & $0.26 \pm 0.02 \mathrm{a}$ \\
\hline 24 & St. Martin's Island & $2.13 \pm 0.53 \mathrm{i}$ & $0.00 \pm 0.00 \mathrm{e}$ & $0.02 \pm 0.02 \mathrm{jk}$ & $0.16 \pm 0.04 b c$ \\
\hline
\end{tabular}

$\mathrm{SE}=$ Standard error, $\mathrm{n}=24$. In the column, mean values bearing similar letter(s) or without letter are identical and those having dissimilar letters are differed significantly as per Duncan's Multiple Range Test.

Epidermal cell length was highest in St. Martin's Island $(80.06 \mu \mathrm{m})$ and lowest in Faridpur $(23.07 \mu \mathrm{m})$ in abaxial surface of the leaves (Table 4). Epidermal cell length was highest in Barguna $(72.06 \mu \mathrm{m})$ and lowest in Khulna $(28.76 \mu \mathrm{m})$ in adaxial surface of the leaves (Table 8). Epidermal cell breadth was highest in case of Cox's Bazar $(21.74 \mu \mathrm{m})$ and lowest in case of Khulna $(7.31 \mu \mathrm{m})$ in abaxial surface of the leaves (Table 4). Epidermal cell breadth was highest in case of Cox's Bazar $(12.20 \mu \mathrm{m})$ and lowest in case of Faridpur $(7.10 \mu \mathrm{m})$ in adaxial surface of the leaves (Table 8). The epidermis consists of various types of functionally specialized cells play vital role in restricting water loss, regulate gaseous exchange, defense, attract pollinators, photosynthesis, transpiration, respiration, mechanical strength and flexibility. Palmer and Tucker (1981) also observed that foliar epidermal features were useful in the systematics and 
characterization within sub families and tribes. Many leaf epidermal characters such as length and shape of epidermal cells, stomata, stomatal type, papillae, prickle angular, macro and micro hair, hooks, margins and silica bodies are taxonomically informative and can be used as an important tool in the delimitation of grasses (Prat, 1932; Metcalfe, 1960; Ellis, 1979; Petronela and Nevana, 2010). Watson and Dallwitz (1992) reported detailed description of the leaf epidermis in numerous taxa, pointing out the significance of these characters in the systematics of the Poaceae.

Table 6. Quantitative epidermal characteristics on adaxial surface of leaves of Cynodon dactylon collected from different habitats of Bangladesh.

\begin{tabular}{|c|c|c|c|c|}
\hline $\begin{array}{l}\text { Sl. } \\
\text { No. }\end{array}$ & Habitats & Long cells $/ \mathrm{mm}^{2}$ & $\begin{array}{l}\text { Long cell length } \\
(\mu \mathrm{m})\end{array}$ & $\begin{array}{l}\text { Long cell width } \\
(\mu \mathrm{m})\end{array}$ \\
\hline 1 & Rangpur & $5.88 \pm 0.50$ efghij & $37.72 \pm 0.82 \mathrm{mn}$ & $6.63 \pm 0.42 \mathrm{~cd}$ \\
\hline 2 & Lalmonirhat & $5.33 \pm 0.52 \mathrm{hij}$ & $50.12 \pm 0.70 \mathrm{~g}$ & $7.73 \pm 0.24 b c$ \\
\hline 3 & Dinajpur & $5.15 \pm 0.20 \mathrm{ij}$ & $48.85 \pm 0.76 \mathrm{~g}$ & $7.39 \pm 0.34 b c$ \\
\hline 4 & Thakurgaon & $9.20 \pm 0.44 \mathrm{a}$ & $72.69 \pm 0.61 b$ & $7.68 \pm 0.44 b c$ \\
\hline 5 & Panchagarh & $9.01 \pm 0.30 \mathrm{a}$ & $41.98 \pm 0.87 \mathrm{jk}$ & $6.53 \pm 0.24 \mathrm{~cd}$ \\
\hline 6 & Gaibandha & $8.46 \pm 0.32 \mathrm{ab}$ & $41.16 \pm 0.67 \mathrm{kl}$ & $7.40 \pm 0.36 b c$ \\
\hline 7 & Rajshahi & $6.81 \pm 0.60 \mathrm{cdef}$ & $36.05 \pm 0.76 n$ & $7.51 \pm 0.56 b c$ \\
\hline 8 & Naogaon & $7.50 \pm 0.40 \mathrm{bc}$ & $44.09 \pm 0.79 \mathrm{hi}$ & $6.95 \pm 0.56 b c$ \\
\hline 9 & Pabna & $7.43 \pm 0.42 b c$ & $55.46 \pm 0.73 \mathrm{ef}$ & $6.72 \pm 0.58 \mathrm{~cd}$ \\
\hline 10 & Gazipur & $6.32 \pm 0.58$ cdefghi & $33.06 \pm 0.58 \mathrm{o}$ & $7.73 \pm 0.24 b c$ \\
\hline 11 & Narsingdi & $7.17 \pm 0.52 \mathrm{bcde}$ & $43.55 \pm 0.79 \mathrm{hij}$ & $6.61 \pm 0.38 \mathrm{~cd}$ \\
\hline 12 & Sherpur & $4.61 \pm 0.38 \mathrm{j}$ & $54.26 \pm 0.82 f$ & $5.39 \pm 0.34 \mathrm{de}$ \\
\hline 13 & Mymensingh & $5.75 \pm 0.20$ fghij & $49.95 \pm 0.84 \mathrm{~g}$ & $7.10 \pm 0.54 b c$ \\
\hline 14 & Khulna & $6.75 \pm 0.34 \mathrm{cdefg}$ & $64.69 \pm 0.61 \mathrm{c}$ & $4.62 \pm 0.40 \mathrm{ef}$ \\
\hline 15 & Jessore & $6.34 \pm 0.54$ cdefghi & $56.66 \pm 0.58 \mathrm{e}$ & $6.63 \pm 0.42 \mathrm{~cd}$ \\
\hline 16 & Jhenaidah & $6.60 \pm 0.28 \mathrm{cdefgh}$ & $59.53 \pm 0.79 \mathrm{~d}$ & $6.94 \pm 0.26 b c$ \\
\hline 17 & Faridpur & $5.92 \pm 0.36$ defghij & $42.03 \pm 0.61 \mathrm{ijk}$ & $6.64 \pm 0.44 \mathrm{~cd}$ \\
\hline 18 & Shariatpur & $9.65 \pm 0.52 \mathrm{a}$ & $31.39 \pm 0.64 p$ & $4.92 \pm 0.22 \mathrm{e}$ \\
\hline 19 & Barguna & $3.31 \pm 0.20 \mathrm{k}$ & $90.76 \pm 0.67 \mathrm{a}$ & $8.28 \pm 0.50 b$ \\
\hline 20 & Khagrachari & $5.43 \pm 0.42$ ghij & $54.45 \pm 0.76 f$ & $7.92 \pm 0.58 b c$ \\
\hline 21 & Bandarban & $6.92 \pm 0.36 \mathrm{cdef}$ & $44.98 \pm 0.87 \mathrm{~h}$ & $7.02 \pm 0.40 \mathrm{bc}$ \\
\hline 22 & Rangamati & $6.62 \pm 0.40 \mathrm{cdefgh}$ & $39.32 \pm 0.581 \mathrm{~m}$ & $3.40 \pm 0.36 \mathrm{f}$ \\
\hline 23 & Cox's Bazar & $3.33 \pm 0.24 \mathrm{k}$ & $72.95 \pm 0.84 b$ & $12.33 \pm 0.60 \mathrm{a}$ \\
\hline 24 & St. Martin's Island & $7.28 \pm 0.44 \mathrm{bcd}$ & $58.98 \pm 0.87 \mathrm{~d}$ & $7.85 \pm 0.60 b c$ \\
\hline
\end{tabular}

$\mathrm{SE}=$ Standard error, $\mathrm{n}=24$. In the column, mean values bearing similar letter(s) or without letter are identical and those having dissimilar letters are differed significantly as per Duncan's Multiple Range Test. 
Table 7. Quantitative epidermal characteristics on adaxial surface of leaves of Cynodon dactylon collected from different habitats of Bangladesh.

\begin{tabular}{|c|c|c|c|c|}
\hline $\begin{array}{l}\text { Sl. } \\
\text { No. }\end{array}$ & Habitats & $\begin{array}{l}\text { Stomatal } \\
\text { frequency }\end{array}$ & Epidermal cell $/ \mathrm{mm}^{2}$ & Stomatal index \\
\hline 1 & Rangpur & $5.21 \pm 0.24 \mathrm{bcde}$ & $16.06 \pm 0.73 \mathrm{cdef}$ & $25.77 \pm 0.59 b c$ \\
\hline 2 & Lalmonirhat & $4.59 \pm 0.42 \mathrm{defg}$ & $13.20 \pm 0.82 \mathrm{hi}$ & $26.67 \pm 0.36 b$ \\
\hline 3 & Dinajpur & $5.15 \pm 0.56 \mathrm{bcde}$ & $14.95 \pm 0.70 \mathrm{efgh}$ & $26.07 \pm 0.46 b c$ \\
\hline 4 & Thakurgaon & $6.29 \pm 0.38 \mathrm{ab}$ & $19.03 \pm 0.70 \mathrm{ab}$ & $25.43 \pm 0.33 b c$ \\
\hline 5 & Panchagarh & $5.44 \pm 0.22 \mathrm{abcde}$ & $16.05 \pm 0.79 \mathrm{cdef}$ & $26.81 \pm 0.64 b$ \\
\hline 6 & Gaibandha & $6.31 \pm 0.56 \mathrm{ab}$ & $18.85 \pm 0.76 \mathrm{ab}$ & $25.73 \pm 0.56 b c$ \\
\hline 7 & Rajshahi & $5.29 \pm 0.38$ bcde & $15.98 \pm 0.73 \mathrm{cdef}$ & $25.93 \pm 0.64 b c$ \\
\hline 8 & Naogaon & $5.76 \pm 0.28 \mathrm{abcd}$ & $17.69 \pm 0.79 \mathrm{bcd}$ & $25.60 \pm 0.46 b c$ \\
\hline 9 & Pabna & $4.61 \pm 0.38 \mathrm{cdefg}$ & $13.57 \pm 0.76 \mathrm{ghi}$ & $26.07 \pm 0.28 b c$ \\
\hline 10 & Gazipur & $3.85 \pm 0.24$ fghi & $11.85 \pm 0.61 \mathrm{ij}$ & $25.80 \pm 0.61 b c$ \\
\hline 11 & Narsingdi & $5.92 \pm 0.22 \mathrm{abc}$ & $17.92 \pm 0.82 \mathrm{abc}$ & $25.87 \pm 0.33 b c$ \\
\hline 12 & Sherpur & $4.36 \pm 0.22 \mathrm{efgh}$ & $13.04 \pm 0.64 \mathrm{hi}$ & $26.24 \pm 0.48 b c$ \\
\hline 13 & Mymensingh & $4.86 \pm 0.26 \mathrm{cdefg}$ & $14.89 \pm 0.79 \mathrm{efgh}$ & $25.78 \pm 0.43 b c$ \\
\hline 14 & Khulna & $5.23 \pm 0.20 \mathrm{bcde}$ & $13.89 \pm 0.76$ fghi & $28.76 \pm 0.43 \mathrm{a}$ \\
\hline 15 & Jessore & $5.10 \pm 0.54$ bcdef & $14.76 \pm 0.82 \mathrm{efgh}$ & $26.55 \pm 0.61 b c$ \\
\hline 16 & Jhenaidah & $6.40 \pm 0.44 \mathrm{ab}$ & $19.57 \pm 0.61 \mathrm{ab}$ & $24.97 \pm 0.28 \mathrm{c}$ \\
\hline 17 & Faridpur & $4.96 \pm 0.22 \mathrm{cdef}$ & $15.14 \pm 0.55$ efgh & $25.80 \pm 0.61 b c$ \\
\hline 18 & Shariatpur & $6.61 \pm 0.38 \mathrm{a}$ & $19.99 \pm 0.70 \mathrm{a}$ & $25.40 \pm 0.31 b c$ \\
\hline 19 & Barguna & $3.02 \pm 0.32 \mathrm{i}$ & $9.28 \pm 0.82 \mathrm{k}$ & $26.05 \pm 0.53 b c$ \\
\hline 20 & Khagrachari & $5.37 \pm 0.60 \mathrm{abcde}$ & $15.38 \pm 0.58 \mathrm{defgh}$ & $25.61 \pm 0.31 b c$ \\
\hline 21 & Bandarban & $5.58 \pm 0.32 \mathrm{abcde}$ & $16.49 \pm 0.61 \mathrm{cde}$ & $26.27 \pm 0.61 b c$ \\
\hline 22 & Rangamati & $5.57 \pm 0.60 \mathrm{abcde}$ & $15.66 \pm 0.55 \mathrm{cdefg}$ & $26.37 \pm 0.41 b c$ \\
\hline 23 & Cox's Bazar & $3.34 \pm 0.40 \mathrm{hi}$ & $9.72 \pm 0.67 \mathrm{k}$ & $26.26 \pm 0.33 b c$ \\
\hline 24 & St. Martin's Island & $3.70 \pm 0.32 \mathrm{ghi}$ & $10.48 \pm 0.64 \mathrm{jk}$ & $27.04 \pm 0.41 \mathrm{~b}$ \\
\hline
\end{tabular}

$\mathrm{SE}=$ Standard error, $\mathrm{n}=24$. In the column, mean values bearing similar letter(s) or without letter are identical and those having dissimilar letters are differed significantly as per Duncan's Multiple Range Test.

Number of silica bodies per $\mathrm{mm}^{2}$ was highest in sample of Bandarban (10.26) and lowest in sample of St. Martin's Island (2.13) in abaxial surface of the leaves (Table 5). Number of silica bodies per $\mathrm{mm}^{2}$ was highest in case of Naogaon (7.95) and lowest in case of Cox's Bazar (2.00) in adaxial surface of the leaves (Table 9). Prickles angular number per $\mathrm{mm}^{2}$ was highest in case of Gaibandha (0.32) and lowest in case of Mymensingh (0.19) and no prickles angular was found in case of Barguna, Cox's Bazar and St. Martin's Island in abaxial surface of the leaves (Table 5). Prickles angular number per $\mathrm{mm}^{2}$ was highest in case of Thakurgaon (0.42) and lowest in case of both Pabna and Rangamati (0.18) and no prickles angular was found in case of Barguna, Cox's Bazar and St. Martin's Island in adaxial surface of the leaves (Table 9). Number of hooks per $\mathrm{mm}^{2}$ was highest in case of Rajshahi (0.96) and lowest in case of Thakurgaon (0.02), Sherpur (0.02) 
Table 8. Quantitative epidermal characteristics on adaxial surface of leaves of Cynodon dactylon collected from different habitats of Bangladesh.

\begin{tabular}{|c|c|c|c|c|c|}
\hline $\begin{array}{l}\text { Sl. } \\
\text { No. }\end{array}$ & Habitats & $\begin{array}{l}\text { Stomata length } \\
\text { with guard cell } \\
(\mu \mathrm{m})\end{array}$ & $\begin{array}{l}\text { Stomata breadth } \\
\text { with guard cell } \\
(\mu \mathrm{m})\end{array}$ & $\begin{array}{l}\text { Epidermal cell } \\
\text { length }(\mu \mathrm{m})\end{array}$ & $\begin{array}{l}\text { Epidermal cell } \\
\text { breadth } \\
(\mu \mathrm{m})\end{array}$ \\
\hline 1 & Rangpur & $12.42 \pm 0.73 \mathrm{ef}$ & $8.77 \pm 0.30 \mathrm{fgh}$ & $38.79 \pm 0.70 \mathrm{i}$ & $8.33 \pm 0.60 \mathrm{defgh}$ \\
\hline 2 & Lalmonirhat & $14.02 \pm 0.87 \mathrm{cde}$ & $10.73 \pm 0.24 \mathrm{c}$ & $34.16 \pm 0.73 \mathrm{k}$ & $8.43 \pm 0.42$ defgh \\
\hline 3 & Dinajpur & $12.50 \pm 0.84 \mathrm{ef}$ & $9.81 \pm 0.38 \mathrm{cdef}$ & $38.22 \pm 0.79 \mathrm{ij}$ & $7.53 \pm 0.60 \mathrm{gh}$ \\
\hline 4 & Thakurgaon & $13.69 \pm 0.55 \mathrm{cdef}$ & $9.35 \pm 0.52$ defgh & $42.69 \pm 0.61 \mathrm{gh}$ & $8.19 \pm 0.34$ efgh \\
\hline 5 & Panchagarh & $15.41 \pm 0.76 \mathrm{abcd}$ & $9.77 \pm 0.60 \mathrm{cdef}$ & $47.29 \pm 0.55 \mathrm{e}$ & $8.17 \pm 0.30$ efgh \\
\hline 6 & Gaibandha & $13.42 \pm 0.73 \mathrm{def}$ & $9.79 \pm 0.34 \mathrm{cdef}$ & $37.45 \pm 0.70 \mathrm{ij}$ & $8.11 \pm 0.56 \mathrm{efgh}$ \\
\hline 7 & Rajshahi & $15.29 \pm 0.61 \mathrm{abcd}$ & $8.83 \pm 0.30$ efgh & $33.15 \pm 0.84 \mathrm{k}$ & $9.11 \pm 0.56 \mathrm{bcdef}$ \\
\hline 8 & Naogaon & $15.66 \pm 0.58 \mathrm{abcd}$ & $12.19 \pm 0.34 b$ & $37.72 \pm 0.82 \mathrm{ij}$ & $10.18 \pm 0.56 b c$ \\
\hline 9 & Pabna & $12.66 \pm 0.73 \mathrm{ef}$ & $9.83 \pm 0.42 \mathrm{cdef}$ & $29.52 \pm 0.64 \mathrm{~m}$ & $8.33 \pm 0.60 \mathrm{defgh}$ \\
\hline 10 & Gazipur & $14.09 \pm 0.67 \mathrm{cde}$ & $8.80 \pm 0.28 f g h$ & $38.62 \pm 0.55 \mathrm{i}$ & $9.81 \pm 0.38 \mathrm{bcd}$ \\
\hline 11 & Narsingdi & $14.29 \pm 0.61 \mathrm{cde}$ & $8.37 \pm 0.38 \mathrm{gh}$ & $33.85 \pm 0.76 \mathrm{k}$ & $8.38 \pm 0.20 \mathrm{defgh}$ \\
\hline 12 & Sherpur & $15.57 \pm 0.61 \mathrm{abcd}$ & $9.38 \pm 0.32$ defgh & $40.85 \pm 0.76 h$ & $8.74 \pm 0.46 \mathrm{cdefg}$ \\
\hline 13 & Mymensingh & $11.56 \pm 0.67 f$ & $8.78 \pm 0.32 \mathrm{fgh}$ & $51.79 \pm 0.70 \mathrm{~d}$ & $7.99 \pm 0.34 \mathrm{fgh}$ \\
\hline 14 & Khulna & $12.62 \pm 0.55 \mathrm{ef}$ & $8.11 \pm 0.20 \mathrm{~h}$ & $28.76 \pm 0.67 \mathrm{~m}$ & $8.11 \pm 0.20 \mathrm{efgh}$ \\
\hline 15 & Jessore & $13.42 \pm 0.73 \mathrm{def}$ & $9.41 \pm 0.38$ defgh & $54.69 \pm 0.61 \mathrm{c}$ & $8.31 \pm 0.56 \mathrm{defgh}$ \\
\hline 16 & Jhenaidah & $14.22 \pm 0.73 \mathrm{cde}$ & $8.70 \pm 0.30 \mathrm{fgh}$ & $44.95 \pm 0.84 f$ & $8.59 \pm 0.58$ defgh \\
\hline 17 & Faridpur & $15.96 \pm 0.82 \mathrm{abc}$ & $10.12 \pm 0.58 \mathrm{cde}$ & $36.36 \pm 0.67 j$ & $7.10 \pm 0.40 \mathrm{~h}$ \\
\hline 18 & Shariatpur & $14.65 \pm 0.76 \mathrm{bcde}$ & $9.50 \pm 0.54 \mathrm{cdefg}$ & $30.72 \pm 0.641 \mathrm{~m}$ & $8.12 \pm 0.22 \mathrm{efgh}$ \\
\hline 19 & Barguna & $16.72 \pm 0.64 \mathrm{ab}$ & $15.62 \pm 0.28 \mathrm{a}$ & $72.06 \pm 0.64 \mathrm{~A}$ & $8.31 \pm 0.56 \mathrm{defgh}$ \\
\hline 20 & Khagrachari & $15.34 \pm 0.55 \mathrm{abcd}$ & $9.50 \pm 0.30 \mathrm{cdefg}$ & $32.66 \pm 0.58 \mathrm{kl}$ & $9.60 \pm 0.36 \mathrm{bcde}$ \\
\hline 21 & Bandarban & $12.57 \pm 0.79 \mathrm{ef}$ & $9.42 \pm 0.40$ defgh & $36.72 \pm 0.64 \mathrm{ij}$ & $8.61 \pm 0.52 \mathrm{defgh}$ \\
\hline 22 & Rangamati & $12.86 \pm 0.58 \mathrm{ef}$ & $8.54 \pm 0.26 f g h$ & $32.66 \pm 0.58 \mathrm{kl}$ & $8.20 \pm 0.36 \mathrm{efgh}$ \\
\hline 23 & Cox's Bazar & $17.14 \pm 0.87 \mathrm{a}$ & $14.93 \pm 0.60 \mathrm{a}$ & $58.96 \pm 0.67 \mathrm{~B}$ & $12.20 \pm 0.36 \mathrm{a}$ \\
\hline 24 & St. Martin's Island & $17.59 \pm 0.70 \mathrm{a}$ & $10.40 \pm 0.36 \mathrm{~cd}$ & $43.96 \pm 0.67 \mathrm{fg}$ & $10.39 \pm 0.42 b$ \\
\hline
\end{tabular}

$\mathrm{SE}=$ Standard error, $\mathrm{n}=24$. In the column, mean values bearing similar letter(s) or without letter are identical and those having dissimilar letters are differed significantly as per Duncan's Multiple Range Test.

and St. Martin's Island (0.02) in abaxial surface of the leaves (Table 5). Number of hooks per $\mathrm{mm}^{2}$ was highest in case of Lalmonirhat (1.69) and lowest in case of Barguna (0.02) in adaxial surface of the leaves (Table 9). In case of Cox's Bazar, hook was absent both abaxial and adaxial surfaces of the leaves (Table $5 \&$ 9). Macro hair number per $\mathrm{mm}^{2}$ was highest in case of Cox's Bazar (0.26) and lowest in case of Khagrachari (0.02) in abaxial surface of the leaves (Table 5). Macro hair number per $\mathrm{mm}^{2}$ was highest in case of Cox's Bazar (0.52) and lowest in in case of Gazipur (0.02) in adaxial surface of the leaves. No macro hair was found in the sample of Pabna (Table 9). However, all these characters were found to be highest and lowest both abaxially and adaxially, which indicates the taxonomic importance of the foliar characters. The foliar epidermis offers a 
Table 9. Quantitative epidermal characteristics on adaxial surface of leaves of Cynodon dactylon collected from different habitats of Bangladesh.

\begin{tabular}{|c|c|c|c|c|c|}
\hline $\begin{array}{l}\text { Sl. } \\
\text { No. }\end{array}$ & Habitats & $\begin{array}{l}\text { Silica bodies } \\
\text { no. } / \mathrm{mm}^{2}\end{array}$ & $\begin{array}{l}\text { Prickles } \\
\text { angular } / \mathrm{mm}^{2}\end{array}$ & Hooks no. $/ \mathrm{mm}^{2}$ & $\begin{array}{l}\text { Macro hair } \\
\text { no. } / \mathrm{mm}^{2}\end{array}$ \\
\hline 1 & Rangpur & $5.69 \pm 0.30 \mathrm{~cd}$ & $0.30 \pm 0.02 \mathrm{cdef}$ & $0.52 \pm 0.00 \mathrm{f}$ & $0.11 \pm 0.03 \mathrm{de}$ \\
\hline 2 & Lalmonirhat & $4.89 \pm 0.52 \mathrm{~d}$ & $0.39 \pm 0.03 \mathrm{ab}$ & $1.69 \pm 0.01 \mathrm{a}$ & $0.24 \pm 0.04 b c$ \\
\hline 3 & Dinajpur & $5.73 \pm 0.30 \mathrm{~cd}$ & $0.22 \pm 0.02 \mathrm{fg}$ & $0.98 \pm 0.02 \mathrm{~d}$ & $0.16 \pm 0.04 \mathrm{~cd}$ \\
\hline 4 & Thakurgaon & $6.77 \pm 0.60 \mathrm{abc}$ & $0.42 \pm 0.02 \mathrm{a}$ & $1.54 \pm 0.02 b$ & $0.11 \pm 0.03 \mathrm{de}$ \\
\hline 5 & Panchagarh & $5.09 \pm 0.52 \mathrm{~d}$ & $0.24 \pm 0.04 \mathrm{defg}$ & $0.32 \pm 0.04 \mathrm{j}$ & $0.06 \pm 0.02 \mathrm{efg}$ \\
\hline 6 & Gaibandha & $6.48 \pm 0.44 b c$ & $0.28 \pm 0.04 \mathrm{cdef}$ & $0.48 \pm 0.04$ fgh & $0.04 \pm 0.00 \mathrm{efg}$ \\
\hline 7 & Rajshahi & $5.69 \pm 0.38 \mathrm{~cd}$ & $0.24 \pm 0.04 \mathrm{defg}$ & $1.62 \pm 0.02 \mathrm{a}$ & $0.25 \pm 0.01 \mathrm{~b}$ \\
\hline 8 & Naogaon & $7.95 \pm 0.20 \mathrm{a}$ & $0.30 \pm 0.02 \mathrm{cde}$ & $0.79 \pm 0.03 \mathrm{e}$ & $0.09 \pm 0.01 \mathrm{defg}$ \\
\hline 9 & Pabna & $5.89 \pm 0.38 \mathrm{~cd}$ & $0.18 \pm 0.02 \mathrm{~g}$ & $0.42 \pm 0.02 \mathrm{ghi}$ & $0.00 \pm 0.00 \mathrm{~g}$ \\
\hline 10 & Gazipur & $5.86 \pm 0.46 \mathrm{~cd}$ & $0.27 \pm 0.03 \mathrm{cdef}$ & $1.08 \pm 0.00 \mathrm{c}$ & $0.02 \pm 0.02 \mathrm{fg}$ \\
\hline 11 & Narsingdi & $6.68 \pm 0.44 a b c$ & $0.26 \pm 0.02 \mathrm{defg}$ & $0.75 \pm 0.03 \mathrm{e}$ & $0.08 \pm 0.04 \mathrm{defg}$ \\
\hline 12 & Sherpur & $4.83 \pm 0.34 \mathrm{~d}$ & $0.32 \pm 0.00 \mathrm{bcd}$ & $0.36 \pm 0.04 \mathrm{ij}$ & $0.06 \pm 0.02 \mathrm{efg}$ \\
\hline 13 & Mymensingh & $5.65 \pm 0.24 \mathrm{~cd}$ & $0.30 \pm 0.02 \mathrm{cdef}$ & $1.11 \pm 0.03 c$ & $0.11 \pm 0.03 \mathrm{def}$ \\
\hline 14 & Khulna & $6.87 \pm 0.20 \mathrm{abc}$ & $0.22 \pm 0.02 \mathrm{efg}$ & $0.46 \pm 0.02 \mathrm{fgh}$ & $0.05 \pm 0.01 \mathrm{efg}$ \\
\hline 15 & Jessore & $5.75 \pm 0.42 \mathrm{~cd}$ & $0.35 \pm 0.03 \mathrm{abc}$ & $1.11 \pm 0.03 \mathrm{c}$ & $0.13 \pm 0.01 \mathrm{de}$ \\
\hline 16 & Jhenaidah & $6.56 \pm 0.58 b c$ & $0.39 \pm 0.03 \mathrm{ab}$ & $1.05 \pm 0.01 \mathrm{~cd}$ & $0.10 \pm 0.02 \mathrm{def}$ \\
\hline 17 & Faridpur & $5.79 \pm 0.34 \mathrm{~cd}$ & $0.35 \pm 0.03 \mathrm{abc}$ & $0.42 \pm 0.02 \mathrm{ghi}$ & $0.12 \pm 0.00 \mathrm{de}$ \\
\hline 18 & Shariatpur & $6.88 \pm 0.28 \mathrm{abc}$ & $0.26 \pm 0.02 \mathrm{defg}$ & $0.43 \pm 0.03 \mathrm{ghi}$ & $0.03 \pm 0.03 \mathrm{efg}$ \\
\hline 19 & Barguna & $2.38 \pm 0.32 \mathrm{e}$ & $0.00 \pm 0.00 \mathrm{~h}$ & $0.02 \pm 0.02 \mathrm{k}$ & $0.08 \pm 0.04 \mathrm{defg}$ \\
\hline 20 & Khagrachari & $6.89 \pm 0.30 \mathrm{abc}$ & $0.41 \pm 0.01 \mathrm{a}$ & $1.52 \pm 0.04 b$ & $0.16 \pm 0.04 \mathrm{~cd}$ \\
\hline 21 & Bandarban & $6.15 \pm 0.34 \mathrm{~cd}$ & $0.26 \pm 0.02 \mathrm{defg}$ & $0.50 \pm 0.02 \mathrm{fg}$ & $0.07 \pm 0.03 \mathrm{defg}$ \\
\hline 22 & Rangamati & $7.67 \pm 0.20 \mathrm{ab}$ & $0.18 \pm 0.02 \mathrm{~g}$ & $0.40 \pm 0.04 \mathrm{hi}$ & $0.11 \pm 0.03 \mathrm{de}$ \\
\hline 23 & Cox's Bazar & $2.00 \pm 0.58 \mathrm{e}$ & $0.00 \pm 0.00 \mathrm{~h}$ & $0.00 \pm 0.00 \mathrm{k}$ & $0.52 \pm 0.04 \mathrm{a}$ \\
\hline 24 & St. Martin's Island & $2.55 \pm 0.56 \mathrm{e}$ & $0.00 \pm 0.00 \mathrm{~h}$ & $0.04 \pm 0.04 \mathrm{k}$ & $0.24 \pm 0.04 b c$ \\
\hline
\end{tabular}

$\mathrm{SE}=$ Standard error, $\mathrm{n}=24$. In the column, mean values bearing similar letter(s) or without letter are identical and those having dissimilar letters are differed significantly as per Duncan's Multiple Range Test.

Number of noteworthy taxonomic characters. The biosystematic and taxonomic studies of a number of families established the importance of leaf epidermis (Baranova, 1972; Raju, 1981; Stace, 1984). Although the taxonomists realized lately the importance of micromorphology of the epidermis and thus, the taxonomic monographs are now considered incomplete without it (Rejdali, 1991). The diversity and distributional pattern of the above mentioned characters can be viewed from different perspectives and used as a model system for investigations into developmental biology, ecology, physiology, morphology and evolution. 


\section{Conclusion}

Different parameters of leaf epidermal anatomy like long cells, silica bodies, prickles angular and hook might be helpful in identification of the accessions of $C$. dactylon particularly in case of the grasses collected from hilly regions of Bangladesh. This study mainly focused on qualitative and quantitative characters of twenty four habitats of $C$. dactydon and all of them were amphistomatus. Stomatal parameters like size and number were found to show great ecological importance especially in case of stress tolerance. The stomatal index and stomatal frequency were of vital value in the delimitation of close relation of accessions when their variations were found to be statistically significant in most of the cases. The present findings have indicated that attempts can be made in future using stomatal characters along with few other epidermal features as the aid in identification and classification of Cynodon dactylon at different ecological zones of Bangladesh.

\section{Acknowledgement}

The anatomical part of this research work has been carried out in Plant Ecology Laboratory, and Phycology and Limnology Laboratory of the Department of Botany, University of Rajshahi, Bangladesh and Chairman of the said Department is gratefully acknowledged for providing laboratory support regarding this work.

\section{References}

Abid, R., Sharmeen, S. and Parveen, A. 2007. Stomatal types of monocots within Flora of Karachi, Pakistan. Pak. J. Bot. 39(1): 15-21.

Ahmad, F. 2009. Taxonomic studies of grasses of Salt Range of Pakistan. Department of Plant Sciences Quaid-i-Azam University Islamabad Pakistan. Unpublished thesis, pp. 1-358.

Ahmed, F., Khan, M.A., Ahmed, M., Zafar, M., Nazir, A. and Marwat, S.K. 2010. Ethnomedicinal uses of grasses in Salt Range Region of Northern Pakistan. J. Medicinal Plants Res. 4(5): 362-369.

Ahmed, F., Khan, M.A., Ahmed, M., Arshad, M., Khan, A., Raja, N.I. and Rehman, Z. 2011. Foliar epidermal anatomy as an aid to the identification of grasses in tribe Aveneae (subfamily Pooideae, Poaceae) from salt range of Pakistan. J. Medicinal Plants Res. 5(1): 81-87.

Ahmed, F., Hameed, M., Ashraf, M., Ahmad, M., Khan, A., Nawaz, T., Ahmad K.S. and Zafar, M. 2012. Role of leaf epidermis in identification and differentiation of grasses in tribe Chlorideae (Poaceae) from Pakistan. J. Medicinal Plants Res. 6(10): 1955-1960.

Baranova, M. 1972. Systematic anatomy of the leaf epidermis in the Magnoliaceae and some related families. Taxon 21: 447-469.

Barber, J.L., Thomas, G.O., Kerstiens, G. and Jones, K.C. 2004. Current issues and uncertainties in the measurement and modelling of air-vegetation exchanged within plant processing of POPs. Environmental Pollution, 128: 99-138.

Beerling, D.J. 1995. Stomatal responses to variegated leaves to $\mathrm{CO}_{2}$ enrichment. Annals Bot. 75: 507-511.

Bray, S. and Reid, D.M. 2002. The effect of salinity and $\mathrm{CO}_{2}$ enrichment on the growth and anatomy of the second trifoliate leaf of Phaseolus vulgaris. Canadian J. Bot. 80: 349-359.

Brown, D. 1984. Prospects and limits of phytolith key for grasses in central United States. J. Arch. Sci. 11: 221-243.

Carpenter, S.B. and Smith, N.D. 1975. Stomatal distribution and size in southern Appalachian hard woods. Canadian J. Bot. 53: 1153-1156.

Chaudhari, S.K., Arshad M., Mustafa, G., Fatima, S., Amjad, M.S. and Yasmeen, F. 2014. Foliar epidermal anatomy of grasses from Thal desert, district Khushab, Pakistan. International Journal of Biosciences. 4(8): $62-70$. 
Chaudhary, A.A., Hameed, M., Ahmad, R. and Hussain, A. 2001a. Phytosociological studies in Chhumbi Surala Wild life sanctuary, Chakwal, Pakistan. Species Diversity 1. International Journal of Agriculture \& Biology 3(4): 369-374.

Chaudhary, M.I., Mumtaz, A.S. and Khan, M.A. 2001b. Leaf epidermal anatomy of medicinal grasses of Islamabad, Attock and Mirpur (Azad Kashmir). Pakistan Journal of Biological Sciences, 4(12): 14661469.

De Castro, E.M., Pereira, F.J. and Paiva, R. 2009. Histologia vegetal: estrutura e funcao de orgaos vegetativos. Lavras: UFLA, v.9, n.4.

Drake, P.L., Froend, R.H. and Franks, P.J. 2013. Smaller, faster stomata: scaling of stomatal size, rate of response, and stomatal conductance. Journal of Exp. Botany 64: 495-505.

Dyki, B., Borkowski, J. and Kowalczyk, W. 1998. Wplyw niedoboru miedzi I stresu wodnego na mikrostrukture powierzchni liscia (Lycopersicon esculentum L.) Acta Agrob, 51:119-125.

Eamus, D. 1991. The interaction of rising $\mathrm{CO}_{2}$ and temperatures with water use efficiency. Plant Cell Environ. 14: 843-852.

Elahi, N.N. and Ashraf, M. 2002. A comparative study of stem epidermis of six sugarcane varieties. Biol. Pak. 48(1\&2):175-184.

Ellis, R.P. 1979. A procedure for standardizing comparative leaf anatomy in the Poaceae II: the epidermis as seen in surface view. Bothalia, 12(4): 641-671.

Fernandez, O.A. and Mujica, B. 1973. Effects of some environmental factors on the differentiation of stomata in Spirodela intermedia. Bot. Gaz. 134: 117-121.

Franks, P.J. and Beerling, D.J. 2009. Maximum leaf conductance driven by $\mathrm{CO}_{2}$ effects on stomatal size and density over geologic time. Proc. Natl. Acad. Sci., USA, 106: 10343-10347.

Franks, P.J., Drake, P.L. and Beerling, D.J. 2009. Plasticity in maximum stomatal conductance constrained by negative correlation between stomatal size and density: an analysis using Eucalyptus globulus. Plant Cell Environ. 32: 1737-1748.

Freire, S.E., Arambarri, A.M., Bayon, N.D., Sancho, G., Urtubey, E., Monti, C., Novoa, M.C. and Colares, M.N. 2005. Epidermal characteristics of toxic plants for cattle from the Salado River basin (Buenos Aires, Argentina). Boil. Soc. Argent. Bot. 40(3-4): 1-28.

Gitz, D.C. and Baker, J.T. 2009. Methods for creating stomatal impressions directly onto archivable slides. Agronomy Journal, 101: 232-236.

Hammed, M., Ashraf, M., Naz, N., Nawaz, T., Batool, R., Fatima, S. and Ahmad, F. 2014. Physiological adaptative characteristics of Imperata cylindrica for salinity tolerance. Biologia, 69(9): 1148-1156.

Hepworth, C., Caine, R.S., Harrison, E.L., Sloan, J. and Gray, J.E. 2018. Stomatal development: focusing on the grasses. Current Opinion in Plant Biology 41: 1-7.

Hetherington, A.M. and Woodward, F.I. 2003. The role of stomata in sensing and driving environmental change. Nature 424(6951): 901-908.

Ishtiaq, M., Maqbool, M., Hussain, T., Bhatti, K.H., Mushtaq, W. and Nadeem, A. 2018. Application of leaf epidermal anatomical technique for identification of some grass species from district Bhimber of Azad Jammu and Kashmir, Pakistan. Pak. J. Bot., 50(5): 1853-1863.

Jian, Z., An-Guo, Z., Yi-Chuan, Shu-Wen, W. and Pei, Q. 2012. Adventitious root growth and relative physiological responses to waterlogging in the seedlings of seashore mallow (Kosteletzkya virginica), a biodiesel plant. Aust. J. Crop Sci. 6: 73-80.

Jones, J.H. 1986. Evolution of the Fagaceae: the implications of foliar features. Annual Missouri Botanical Garden 73: 228-275.

Khan, R., Ahmad, M., Zafar, M. and Ullah, A. 2017. Scanning electron and light microscopy of foliar epidermal characters: a tool for plant taxonomists in the identification of grasses. Microsc. Res. Tech. 80(10): 1123-1140.

Kim, S.J., Hahn, E.J., Heo, J.W. and Paek, K.Y. 2004. Effects of LEDs on net photosynthetic rate, growth and leaf stomata of Chrysantemum plantlets in vitro. Sci. Hort. 101: 143-151. 
Knapp, A.K., Cocke, M., Hamerlynck, E.P. and Owensby, C.E. 1994. Effect of elevated $\mathrm{CO}_{2}$ on stomatal density and distribution in $\mathrm{a}_{4}$ grass and $\mathrm{C}_{4}$ forb under field conditions. Ann. Bot. 74: 595-599.

Kundu, S.K. and Tigerstedt, P.M.A. 1998. Variation in net photosynthesis, stomatal characteristics, leaf area and whole-plant phytomass production among ten provenances of neem (Azadirachta indica). Tree Physiol. 19: 47-52.

Lee, S.H., Tewari, R.K., Hahn, E.J. and Paek, K.Y. 2007. Photon flux density and light quality induce changes in growth, stomatal development, photosynthesis plantlets. Plant Cell Tissue and Organ Culture 90(2): 141-151.

McElwain, J.C. and Chaloner, W.G. 1995. Stomatal density and index of fossil plants track atmospheric carbon dioxide in the Paleozoic. Annals of Botany, 76: 389-395.

Metcalfe, C.R. 1960. Anatomy of Monocotyledons. 1. Gramineae, Clarendon Press, Oxford at the Series 13: 389.

Mulholland, S.C. 1989. Phytolith shape frequencies in North Dakota grasses: a comparison to general patterns. J. Arch. Sci. 16: 489-511.

Nadeau, J.A. and Sack, F.D. 2002. Control of stomatal distribution on the Arabidopsis leaf surface. Science 296: $1697-1700$.

Nitu, S.K. and Islam, S.M.S. and Tarique, M.H. 2019b. Morphological characteristics of different accessions of Cynodon dactylon (L.) Pers. and physico-chemical properties of soil of their growing region in Bangladesh. Int. J. Biosciences, 15(5): 350-369.

Nitu, S.K., Islam, S.M.S. and Tarique, M.H. 2019a. Interphase nuclear phenotype and chromosomal variation in Cynodon dactylon (L.) Pers. J. Bio-Sci. 27: 133-141.

Palmer, P.G. and Tucker, A.E. 1981. A scanning electron microscope survey of the epidermis of East African Grasses. 1. Smith. Contrib. Bot. 49: 1-84.

Petronela, C. and Nevena, K. 2010. Characterization of leaf epidermis of two Sesleria species. J. Plant Dev. 17: $23-28$.

Piperno, D.R. and Peasall, D.M. 1998. The silica bodies of tropical American grasses: Morphology, taxonomy, and implications for grass systematics and fossil phytolith identification. Smithsonian Contrib. Bot. 85: 1-40.

Poole, I. and Kurschner, M. 1999. Stomatal density and index: the practice. In: Jones, T.P., Rowe, N.P. (Eds.), Fossil Plants and Spores: Modern Techniques. The Geological Society, London. pp. 257-260.

Prat, H. 1932. The Epidermis of Gramineae. Ann. Sci. Nat. Bot. 14: 117-324.

Prat, H. 1934. Contribution al etude systematique et histologique de Chloridees. Bull. Soc. Bot. Fr. 81: 475491.

Prat, H. 1961. Emploi des characters epidermiques dans la classification des graminees. pp. 99-102 in recent advances in botany, vol. 1. Toronto Univ. Toronto Press.

Raju, V.S. 1981. Leaf Architecture as an Aid to the systematics of the order euphorbiales. Ph.D. Thesis. Nagarjuna University, Nagarjunanagar, Guntur, India.

Rejdali, M. 1991. Leaf micromorphology and taxonomy of North African species of Sideritis L. (Lamiaceae). Bot J. Linn. Soc. 107: 67-77.

Royer, D.L., Berner, R.A. and Beerling, D.J. 2001. Phanerozoic atmospheric $\mathrm{CO}_{2}$ change: evaluating geochemical and paleobiological approaches. Earth-Science Reviews 54(4): 349-392.

Rudall, P.J., Chen, E.D. and Cullen, E. 2017. Evolution and development of monocot stomata. American Journal Botany 104(8): 1122-1141.

Schoch, P.G., Jacques, R., Lecharny, A. and Sibi, M. 1984. Dependence of the stomatal index on environmental factors during stomatal differentiation in leaves of Vigna sinensis L. II. Effect of different light quality. J. Exp. Bot. 35: 1405-1409.

Simonneau, T., Lebon, E., Coupel-Ledru, A., Margueriti, E., Rossdeutsch, L. and Ollat, N. 2017. Adapting plant material to face water stress in veneyards: which physiological targets for an optimal control of plant water status? OENO One 51(2): 167-179. 
Stace, C.A. 1984. The taxonomic importance of the leaf surface. In: Herwood, V.H. and Moore, D.M., Eds., Current Concepts in Plant Taxonomy, Academy Press, London, pp. 67-94.

Stenglein, S.A., Colares, M.N., Arambarri, A.M., Novoa, M.C., Vizcaino, C.E. and Katinas, L. 2003. Leaf epidermal microcharacters of the old world species of Lotus (Leguminoseae: Loteae) and their systematic significance. Austr. J. Bot. 51: 459-469.

Thomasson, J.R., Nelson, M.E. and Zakrzawski, R.J. 1986. A fossil grass (Gramineae-Chloridoideae) from the Miocene, with Krantz Anatomy Science 233: 876-878.

Tufail, A., Ahmad, F., Hameed, M. and Ahmad, R. 2017. Growth performance and stomatal behavior in relation to ecotypic adaptations in Cynodon dactylon (L.) Pers. Pak. J. Bot. 49: 1395-1403.

Twiss, P.C., Suess, E. and Smith, R.M. 1969. Morphological classification of grass phytoliths. Soil Science of America, Proceedings 33: 109-115.

Uhl, D. and Kerp, H. 2005. Variabilty of stomatal density and index in the upper Permian conifer Quadracladus Madler-a taphonomic case study. Paleogeography, Palaeoclimatology, palaeoecology. 218(3-4): 203-213.

Van De Peer, Y., Mizrachi, E. and Marchal, K. 2017. The evolutionary significance of polyploidy. Nat Rev Genet. 18(7): 411-424.

Vesque, M.J. 1989. Empoly of characters anatomiques dans classification plant. Bull Soc. Bot., France. 36: 41-77.

Vrablova, M., Vrabl, D., Hronkova, M., Kubasek, J. and Santrucek, J. 2017. Stomatal function, density and pattern, and $\mathrm{CO}_{2}$ assimilation in Arabidopsis thaliana tmml and sdd1-1 mutants. Plant Biol. 19: 689701.

Wagner, F., Dilcher, D.L. and Visscher, H. 2005. Stomatal frequency responses in hardwood swamp vegetation from Florida during a 60-year continuous $\mathrm{CO}_{2}$ increase. American Journal of Botany 92(4): $162-168$.

Walsh, G.E. 1990. Anatomy of the seed and seedling of Spartina alterniflora Lois. (Poaceae). Aquat. Bot. 38: 177-193.

Watson, L. and Dallwitz, M.J. 1992. The Grass Genera of the World. CAB International. Wallingford, UK. $1038 \mathrm{pp}$.

$\mathrm{Xu}, \mathrm{Z}$. and Zhou, G. 2008. Responses of leaf stomatal density to water status and its relationship with photosynthesis in a grass. Exp. Bot. 59(12): 3317-3325.

Zheng, Y., Xu, M., Hou, R., Shen, R., Qiu, S. and Ouyang, Z. 2013. Effects of experimental warming on stomatal traits in leaves of maize (Zea mays L.). Ecol. Evol. 3(9): 3095-3111.

(Manuscript received on 02 July, 2020; revised on 12 November, 2020) 